\title{
Biostratigraphy and palaeoecology of the marine Pleistocene of Rhodes, Greece: Scleractinia, Serpulidae, Mollusca and Brachiopoda
}

\author{
Jan Kresten Nielsen, Nils-Martin Hanken, Jesper Kresten Nielsen \& Kim Sten Hansen
}

\begin{abstract}
A biostratigraphical and palaeoecological study of the Pleistocene marine fauna from the Kallithea area (northeast Rhodes, Greece) has been conducted. In this area, the Lindos Bay Clay and the Cape Arkhangelos Calcarenite, which constitute the Rhodes Formation, are well exposed in ancient quarries. The study has revealed the presence of 120 mollusc taxa, viz scaphopods (3 taxa), bivalves (65), gastropods (52) and indeterminate polyplacophorans, together with brachiopods (6 taxa), corals (3) and serpulids (7). The fauna of the Lindos Bay Clay contains counterparts of the modern biocoenoses of the coastal detritic (DC) and muddy detritic bottoms (DE), whereas the Cape Arkhangelos Calcarenite shows evidence of the coralligenous biocoenosis (C), the biocoenosis of the "Posidonia" meadows (HP), the biocoenosis of the photophilic algae (AP), the biocoenosis of fine-grained, well-sorted sand (SFBC), and the biocoenosis of coarse-grained sands and fine gravels under bottom currents (SGCF). The Windmill Bay Boulder Bed and the Kleopolu Calcirudite, which comprise the overlying Lindos Acropolis Formation, contain indeterminate bivalves and gastropods between eroded blocks from the Cape Arkhangelos Calcarenite. The Lindos Acropolis Formation shows remains of the coralligenous biocoenosis (C). The taxa identified confirm the warm-temperate conditions in the northeastern Mediterranean during the Pleistocene. Finds of Arctica islandica, which can be considered a "northern guest", indicate the Pleistocene age of the Cape Arkhangelos Calcarenite. Two uranium/thorium dates of bivalves also support this age. Pteropods in the uppermost Lindos Bay Clay also suggest a Pleistocene age. Key words: marine invertebrates, Pleistocene, Rhodes Formation, Lindos Acropolis Formation, Greece.
\end{abstract}

NIELSEN, J.K., HANKEN, N.-M., NIELSEN, J.K. \& HANSEN, K.S. 2006. Biostratigraphy and palaeoecology of the marine Pleistocene of Rhodes, Greece: Scleractinia, Serpulidae, Mollusca and Brachiopoda. Bulletin of Geosciences 81(3), 173-196 (7 figures, 3 tables). Czech Geological Survey, Prague. ISSN 1214-1119. Typescript received March 22, 2006; accepted in revised form August 7, 2006; issued September 30, 2006.

Jan Kresten Nielsen, Statoil ASA, Exploration \& Production Norway, P.O. Box 273, NO-7501 Stjørdal, Norway; bioerosion@yahoo.dk•Nils-Martin Hanken \& Jesper Kresten Nielsen, Department of Geology, University of Tromsø, Dramsveien 201, NO-9037 Tromsø, Norway • Kim Sten Hansen, VUC FYN, Enggade 15, DK-5000 Odense C, Denmark

The Greek island of Rhodes is a classic study area for sedimentologists and palaeontologists because of its widespread, well-preserved fossiliferous deposits. The first investigations of foraminiferans, ostracods and invertebrate macrofossils from Rhodes were carried out in the nineteenth century (e.g., Fischer 1877, Terquem 1878). During the 1920s and 1930s, Italian geologists published a number of papers about the geology of Rhodes (e.g., Migliorini 1925, 1934a, 1934b, Bevilacqua 1928, Airaghi 1930), and members of the Società Geologica Italiana attended excursions during the $46^{\text {th }}$ Congress in 1933 that mainly took place on that island. This included a trip to "Terme di Calitea" on northeast Rhodes, where oysters and gastropods were reported from exposed Quaternary sediments, the so-called "panchina" (Migliorini 1934b). The name "Terme di Calitea" is synonymous with "Kallithea"
$\left(K \alpha \lambda \lambda \imath \theta^{\prime} \varepsilon \alpha\right)$ and "Thermes Kalitheas", referring to the thermae built in 1929-1930 by the Italian architect Pietro Lombardi. Kallithea is located $8 \mathrm{~km}$ south of the town of Rhodes (Fig. 1). New investigations of this area were made by Lønøy \& Hanken (1989), Nielsen (1997), and Hansen (1999), concentrating on facies relationships and investigations of the rich invertebrate fauna and calcareous red algae. Bioturbation is also widespread, but so far only the trace fossils made by irregular sea urchins in giant foresets (clinoforms) have been described by Bromley \& Asgaard (1975) and Asgaard \& Bromley (1996).

Mutti et al. (1970) gave a thorough revision of the regional geology of Rhodes including an overview of previous faunal studies. The revision of the Cenozoic sequence, however, was based on an inadequate lithostratigraphical 


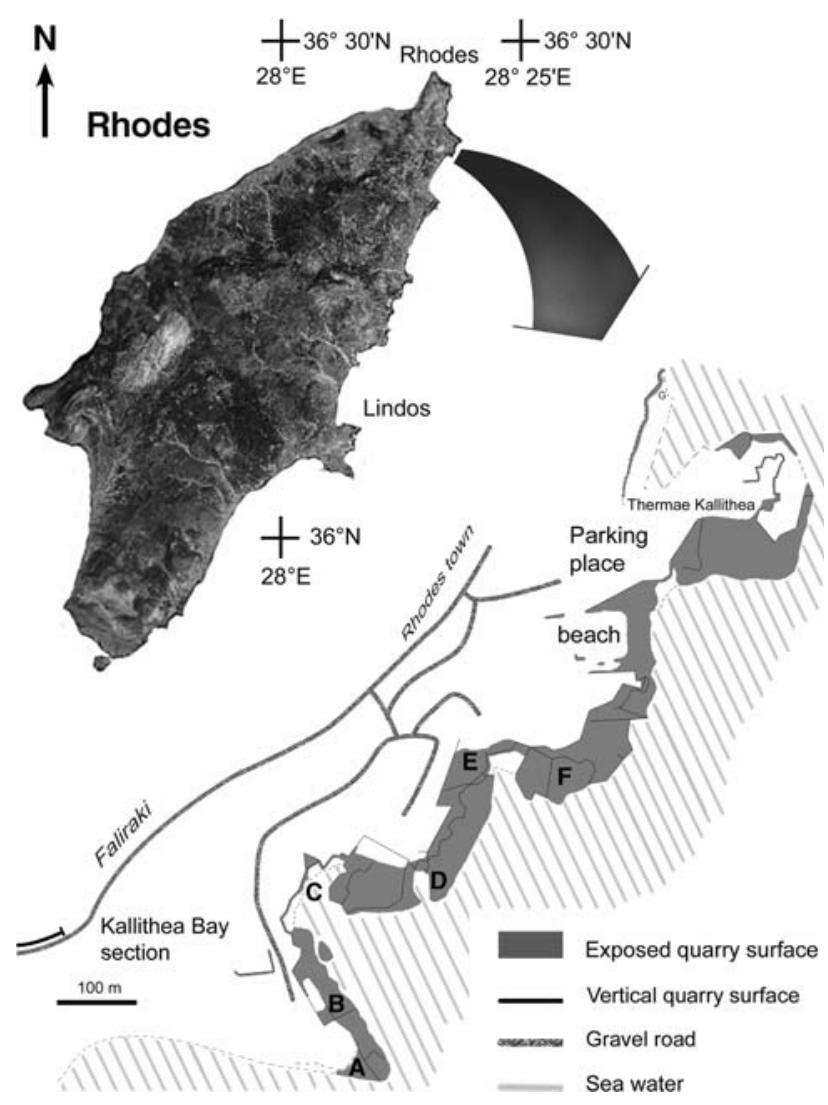

Figure 1. Location of the study area on the northeast coast of the Greek island of Rhodes. Letters refer to various parts of the outcrops of Pleistocene deposits at Kallithea. Satellite image obtained from Google Earth.

framework. The Plio-Pleistocene successions of Rhodes were subdivided by Meulenkamp et al. (1972) into four depositional phases. Later, Hanken et al. (1996) suggested that the Plio-Pleistocene successions of northern and eastern Rhodes should be regarded as facies groups in a modern sequence stratigraphy. Kovacs \& Spjeldnaes (1999) have since reviewed the Pliocene-Pleistocene stratigraphy, and Cornée et al. (in press) integrate the tectonic and sedimentological evolution of Rhodes into a geodynamic context for the Aegean fore-arc.

Although the diachronous distribution of facies groups may be confirmed, a detailed biostratigraphy has not yet been established. An updated appraisal of the macrofaunas within their stratigraphical frame is overdue. This paper provides a list of species occurring in the Rhodes Formation and the overlying Lindos Acropolis Formation at Kallithea. A detailed faunal investigation of this part of the sequence has never been published. With the exception of a few cold-water species, all fossils from the study area represent species living in the Mediterranean today. Because the ecology of these living species is often quite well known, it has been possible to use the fossil content of the sediments for bathymetrical interpretation and facies analysis.

\section{Geological setting}

At Kallithea, the oldest part of the sequence consists of the well-bedded, slightly metamorphosed, grey dolomitic Elaphokampos Cherty Limestone (Mutti et al. 1970), which is of Carnian (Late Triassic) to Early Liassic age. According to Mutti et al. (1970), the eastern and northern parts of Rhodes were subaerially exposed from (?)Pontian (Upper Miocene) to Lower or Middle Pliocene times. However, Løvlie et al. (1989) and Rasmussen et al. (2005) have shown that the area did not undergo transgression before the Upper Pliocene; hence, subaerial exposure lasted longer than previously supposed. This subaerial exposure resulted in extensive karstification of the limestone.

Middle to Upper Pliocene tectonic movements caused subsidence of the eastern and northern parts of Rhodes with local deposition of fluvio-lacustrine and brackish deposits (Meulenkamp et al. 1972, Meulenkamp 1985), both of which laterally and vertically grade into a transgressive sequence of marine sediments (Meulenkamp et al. 1972, Rasmussen et al. 2005). This transgression, amounting to a water depth of more than $600 \mathrm{~m}$ and perhaps as much as 800 m (Moissette \& Spjeldnaes 1995), was followed by a Pleistocene regression (Hanken et al. 1996, Kovacs \& Spjeldnaes 1999) that continues today (e.g., Pirazolli et al. 1982, Pirazolli et al. 1989, Kontogianni et al. 2002). The subaerial exposure caused partial erosion of the Plio-Pleistocene deposits and re-exhumation of the underlying karst surface (Meulenkamp 1985). This part of the sequence is therefore only partially preserved, with older basement highs poking through the sediment cover. The most complete sequences are generally found in topographical depressions in the underlying karst landscape, where they can be studied in many outcrops along the present coastline up to about 50-60 $\mathrm{m}$ above present sea level.

Parts of the karst surface developed in the Elaphokampos Cherty Limestone at Kallithea form a southwest-northeast trending hill nearly $3 \mathrm{~km}$ long and $1 \mathrm{~km}$ broad, with a relief of about $135 \mathrm{~m}$ above present sea level (Fig. 1). The surrounding, topographically low-lying areas of the karst landscape are covered by younger Pliocene-Pleistocene sediments.

As shown by Hanken et al. (1996), the Cape Arkhangelos Calcarenite interfingers with the underlying Lindos Bay Clay. The Cape Arkhangelos Calcarenite was deposited during a regression, and is thus characterised by being an upward-shallowing sequence. The local development of the Cape Arkhangelos Calcarenite is quite variable and depends on the local topography. During the regressive phase, skeletal material was produced in shallow water on the topographic highs, and in deeper water areas lateral to the highs. In areas of shallow water (depth less than $10-15 \mathrm{~m}$ ) there would be a rich growth of organisms like calcareous algae, so that several times as much skeletal 
carbonate would be formed per unit area than in deeper water (e.g., Wilson 1975, Schlager 1981). The principle is shown in Fig. 2. In the shallow, highly productive areas, a combination of storms and wave action would continuously rework the bottom sediments. Hence, some of the material would also be carried over the edge of the local "platform" to be transported some distance down the slope. The basin slope and the flatter area close to the lower part of the basement high may consequently have had a higher sedimentation rate than was otherwise usual. Hence, in the vicinity of basement highs, the Cape Arkhangelos Calcarenite can attain an unusually great thickness and contain a mixture of shallow-water allochthonous skeletal material dominated by red algae and a deeper water autochthonous or parautochthonous fauna (cf. Hanken et al. 1996, Hansen 1999). Continued regression with gradual exposure of the basement highs reduced the contribution of material from these areas, and the communities at the base of the highs gradually change from being a mixture of shallow and deeper water skeletal material to a more homogenous community characterised by shallow-water species. These changes in communities thus reflect the shallowing-upward trend through the Cape Arkhangelos Calcarenite.

In this setting at Kallithea, carbonate sediments dominated by calcareous red algae, bivalves and foraminiferans were deposited within the photic, wave-agitated zone, while bryozoan-foraminiferan-brachiopod dominated carbonate sediments were deposited in deeper water. The sedimentary succession has previously been described in detail by Hansen (1999), where the main emphasis was on the spectacular giant foresets and their stacking pattern. The succession can be assigned to four facies groups: Lindos Bay Clay, Cape Arkhangelos Calcarenite (Rhodes Formation), Windmill Bay Boulder Bed, and Kleopolu Calcirudite (Lindos Acropolis Formation).

The Lindos Bay Clay is normally characterised by deep-water mud deposits (Hanken et al. 1996), but in this case it is dominated by a $10-40 \mathrm{~cm}$ thickness of terrigeneous fine sand and gravelly tempestite beds with irregular upper and lower bioturbated contacts. These beds contain lithoclasts and faunal elements derived from shallower water. The uppermost part of the Lindos Bay Clay consists of a bioturbated firmground where the trace fossils are filled with material derived from the overlying calcareous tempestites of the Cape Arkhangelos Calcarenite.

The overlying Cape Arkhangelos Calcarenite can be divided into five facies (Figs 3-5): (A) lower shoreface storm beds of calcareous tempestites and bryozoan packstones that may show storm-derived primary stratification, bioturbated beds and maërl beds; (B) lower shoreface, migrating bars; (C) storm surge channels on the lower shoreface; (D) upper shoreface storm beds of cross-bedded grainstone and rudstone; (E) giant-scale foresets formed during carbonate platform progradation, interrupted by
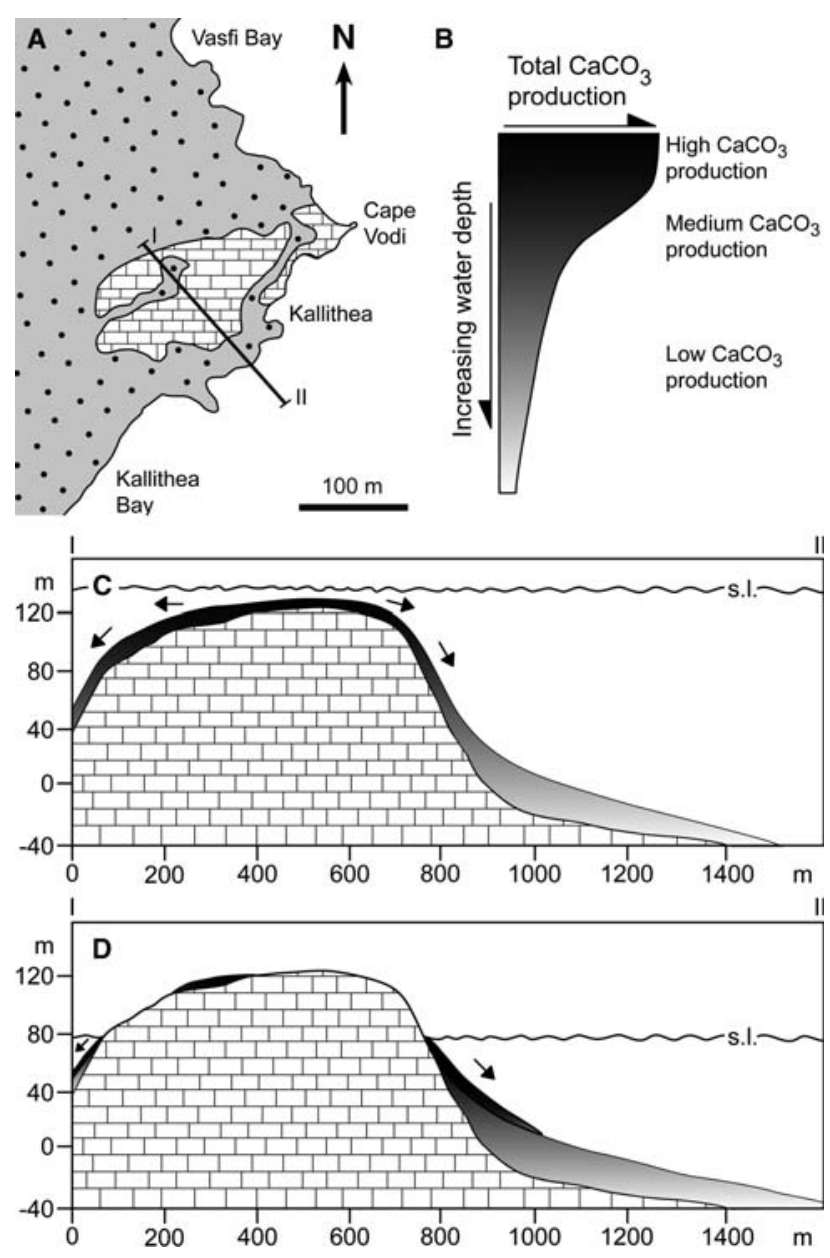

Figure 2. A - distribution of basement and sedimentary deposits at Kallithea. - B - production rate of calcareous sediments compared with the water depth. Total carbonate production is highest in shallow water and becomes greatly reduced as the depth increases. After Handford and Loucks (1993). • C - northwest-southeast profile showing the slope of the basement high west of Kallithea. When sea level was just above the flat-topped basement hill, conditions were favourable for high production of carbonate over a large area. Because of limited accommodation space, part of the sediment production was shed into deeper water, thus accumulating along the foot of the hill. These deposits are therefore characterised by a high sedimentation rate and a mixture of shallow-water and deeper-water organisms. - D - with falling sea level, the coastline ran along a steep mountainside. The area of high carbonate production was therefore limited to a narrow strip near the coast, resulting in substantially less production of shallow-water carbonate. Although a large part of this production was transported down slope, the sedimentation rate along the foot of the hill was reduced. The percentage of deeper-water organisms is higher than in the former case. The importance of the basement high decreases with falling sea level. The fossil assemblage along the foot of the hill consists only of shallow-water organisms.

large-scale scours. The overlying Windmill Bay Boulder Bed and Kleopolu Calcirudite were formed in a foreshore/backshore environment with conglomerates composed of boulders coated with red algae, and beach sands, respectively (Hansen 1999). 
The lower part of the Cape Arkhangelos Calcarenite consists of relatively well-sorted, 5-10 cm thick beds of fine- to medium-grained sandy packstone, with a dominance of Ditrupa. It is overlain by $15-25 \mathrm{~cm}$ thick beds of relatively coarse-grained grainstone to rudstone tempestites with common rhodoliths and abraded bivalves. At Kallithea, a bryozoan wackestone bed up to $1.4 \mathrm{~m}$ thick is found within the tempestite succession (facies A). The sediment is composed of clay to fine sand, and contains robust, and minor delicate, branching bryozoans. A sharp transition then occurs to lower shoreface deposits of mostly packstones and wackestones (facies B and C). The lower surface of the lower shoreface facies shows gutter casts below a hummocky cross-stratified bed. Generally, the succession is composed of upward-fining, bioturbated packstones to wackestones, which are occasionally cut by more than $20 \mathrm{~m}$ wide, sharp-based channels (facies C) with well-sorted grainstone that shows cross-bedding. Low-angle accretionary beds (facies B) reflecting advancing bars on the shoreface are also found.

A sharp transition occurs into the overlying upper shoreface storm beds of grainstones and rudstones (facies D). These beds commonly show small- to large-scale cross-bedding and planar lamination. The beds are fining-upwards and aggrading to prograding.

When the carbonate production next to the basement high exceeded the rate at which new space was made available, the shoreface accreted seawards in the form of giant foresets (facies E). These are up to $12 \mathrm{~m}$ high and may show rhythmic bedding with alternating bioturbated and cross-bedded/laminated giant foresets. These foresets have relatively sparse invertebrate fossils preserved in life position, though echinoid trace fossils may show total bioturbation of the foresets.

The marine succession at Kallithea is capped by sandy beach deposits and grainstone boulders from the Lindos Acropolis Formation, which are covered in red algae. These boulders were formed in very shallow water in a high-energy environment. Lithified grainstones were broken into boulders that became encrusted by calcareous red algae as a form of mega-oncolites.

The four facies groups of the succession form the building blocks of the sedimentary wedge at Kallithea. The deposits of this sedimentary system constitute a temperate-water carbonate platform. During the Pleistocene, the relative sea level at Kallithea was generally falling due to the tectonic uplift of the area. Some surfaces in the succession are therefore indicative of rapid sea-level fall. The sharp transition from the siliciclastic deposits to the calcareous tempestites is one such surface, while the sharp transition from tempestites to the lower shoreface is another such surface. The giant foresets indicate that there was a surplus of calcareous sediments, which was transported in an offshore direction from the main production on the carbonate platform. This surplus was created from newly produced carbonate material and reworked older deposits that originated when the sea level was higher. The ample sediment supply indicates depositional conditions resembling those of the Faliraki scenario of Plio-Pleistocene basin formation. The latter was characterised by Kovacs \& Spjeldnaes (1999) as glacio-eustatic changes and irregularity in topography leading to rapidly changing facies of shallow-marine, brackish and terrestrial origins. Because vertical tectonic movements have also occurred, the actual successions of this scenario are stratigraphically complex (Kovacs \& Spjeldnaes 1999).

\section{Materials and methods}

The larger macrofossils were identified in the field or selectively collected for subsequent identification. To obtain the best possible estimate of the smaller fossils (larger than $0.25 \mathrm{~mm}$ ), a substantial number of bulk samples were also collected from unlithified marl and the least lithified limestones in the remainder of the succession. The haphazard occurrence of material suitable for this type of study in the limestones did not permit standardised sample spacing, and samples were collected where they could be found within the sections. Each sample weighed about $3 \mathrm{~kg}$. The bulk samples were gently wet sieved through standard screens to enable the picking of invertebrate fossils (Nielsen 1997). This technique yielded thousands of relatively well-preserved invertebrates and plant remains ranging in size from several centimetres down to microfossil grade. When matrix breakdown in carbonates had not been satisfactorily achieved by natural weathering, ultrasonic treatment provided further breakdown. Skeletal material within aggregates that resisted the above-mentioned procedures was mechanically extracted and included in the study. All fractions above $0.25 \mathrm{~mm}$ in grain size were picked for specimens, while fractions below $0.25 \mathrm{~mm}$ were not further investigated.

Although there were many taxa, only scleractinians, serpulids, gastropods, bivalves, scaphopods, polyplacophorans and brachiopods were further investigated. The abundance of the skeletal material was specified semiquantitatively: rare (1-3 in number of observed shells), sparse (4-10), common (11-20), frequent (21-100), and very frequent $(>100)$ (Table 1). Bivalves were counted as the highest number of right or left valves, whereas brachiopods were counted by dorsal or ventral valves. Gastropods were similarly counted by the highest number of shell spire or aperature portions. The presence of determinable fragments is also indicated in Table 1.

Hand-picked fossils from the studied succession contained various shells larger than a few millimetres, and these are listed qualitatively in Table 2. Based on field 
observations, the shell occurrences were interpreted by Nielsen (1997) as being autochthonous, parautochthonous or allochthonous. The observations included considerations of shell orientation, disarticulation, fragmentation and encrustations to distinguish whether or not the shells had been transported before final deposition. The shell material is stored in the collections of the Geological Museum, University of Copenhagen.

\section{Results}

Shell remains of invertebrates occur abundantly in the succession at Kallithea (Figs 6, 7). The remains of benthic molluscs were compared with the descriptions and illustrations given by Abbott (1991), Barash \& Danin (1992), Cerulli-Irelli (1907-1912), Chirli (1995), Christensen et al. (1978), D'Angelo \& Gargiullo (1981), Dollfus \& Cotter (1909), Giannuzzi-Savelli et al. (1994), Göthel (1992), J. Knudsen (pers. comm. 1995), Mari \& Zanardi (1971), Nordsieck (1968, 1969), Oliverio \& Buzzurro (1994), Parenzan (1976), Poppe \& Goto (1991, 1993), Riedl (1983), Sneli (1975), Tebble (1976), Tripodi \& Zanardi (1969), Verduin (1976, 1982), Wagner (1991), Willmann (1989) and Zaccaria (1968). The identification of pelagic gastropods follows Bé \& Gilmer (1977) and Spoel (1967), whereas corals and serpulids were determined by Zibrowius (1980, pers. comm. 1994). The binomial nomenclature follows Sabelli et al. (1990-1992) and Giannuzzi-Savelli et al. (1994). A large variety of scaphopods, bivalves, gastropods, brachiopods, scleractinians and serpulids is present in the bulk samples and hand-picked samples (Tables 1 and 2). The Lindos Bay Clay, which comprises the lowermost part of the Kallithea succession, chiefly contains endobenthic bivalves, gastropods and irregular echinoids (Fig. 7). Their occurrence is mainly autochthonous and parautochthonous. In the uppermost bed of the Lindos Bay Clay (sample 98607), solitary corals are also found attached to the posterior end of bivalves in life position as well as on gravel clasts. Terrestrial plant material, especially cones and needles of gymnosperms, occurs sparsely in the facies group.

Each interval (facies A to E) of the Cape Arkhangelos Calcarenite contains coralline red algae in abundance. The algae are mainly present as fragments of branching forms and crusts. Bivalves and gastropods are present throughout the Cape Arkhangelos Calcarenite. However, thin-section studies by Lønøy \& Hanken (1989) have shown that aragonitic skeletal material from the limestone deposits commonly has been selectively dissolved and preserved as moulds. In some cases, the cavity is surrounded by a matrix that must have been partially lithified prior to dissolution of the aragonite fossils (otherwise the cavity would have collapsed, leaving no trace of the original fossil). Commonly,

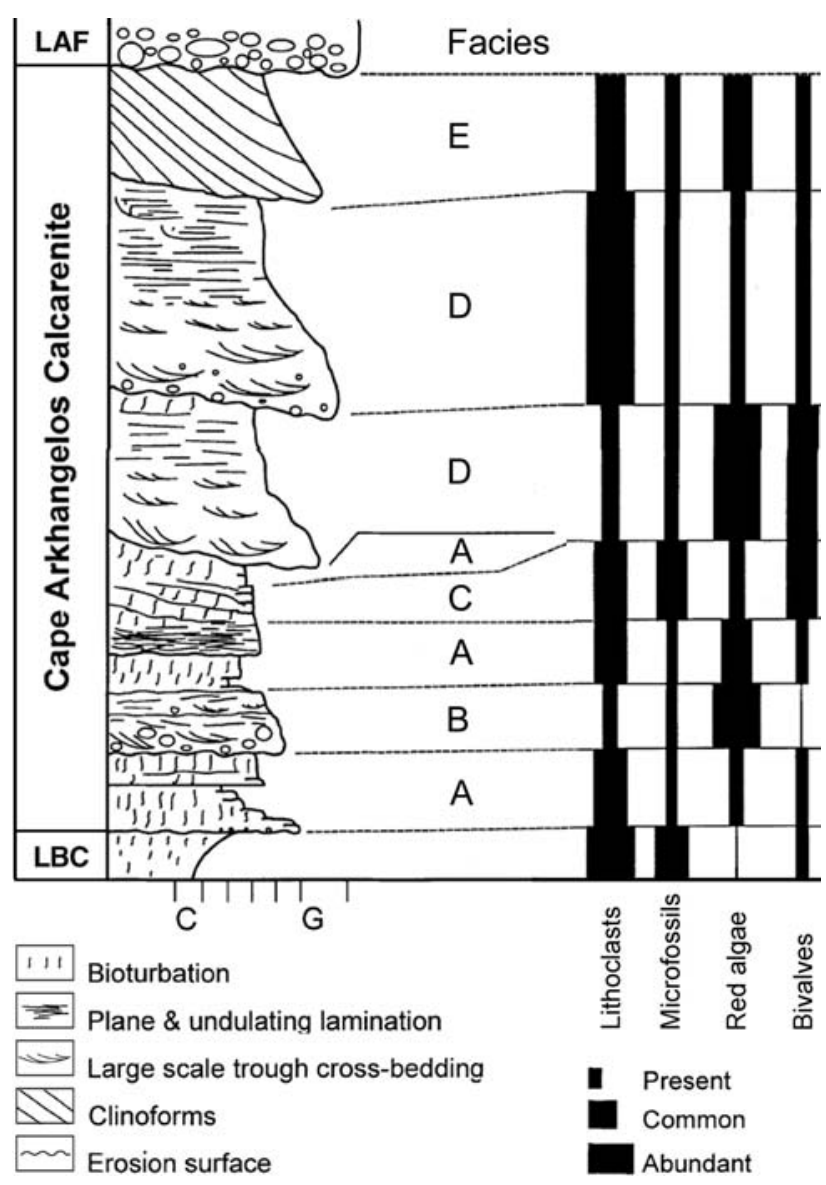

Figure 3. Composite stratigraphical log showing the Pleistocene succession exposed at Kallithea. Adapted from Hansen (1999). Abbreviations: LAF - Lindos Acropolis Formation, LBC - Lindos Bay Clay.

the mould is preserved as a micritic envelope that originated from centripetal micritisation by boring endolithic micro-organisms such as algae, cyanaobacteria and fungi (cf. Bathurst 1966, 1975). Although moulds were sporadically encountered during the sorting process, the selective dissolution of aragonitic fossils in the limestone facies implies that these species have been greatly underrepresented in this investigation. However, aragonitic pteropods were found in the argillaceous parts of the Lindos Bay Clay. The selective preservation of aragonitic skeletal material in this part of the succession is due to the limited percolation of pore water in this poorly permeable sediment.

Worm tubes of Ditrupa sp. are common in the Cape Arkhangelos Calcarenite, and even dominate the macrofauna of the tempestite succession. Pectinids like Pecten jacobaeus, Aequipecten opercularis and Chlamys spp. occur rarely with the worms. This succession also includes a bioturbated bed of wackestone (facies A) characterised by branching bryozoans associated with brachiopods and biomoulds of gastropods. Although the gastropod shells commonly have been dissolved, the biomoulds showed that they were well preserved at final deposition. 
Table 1. Relative abundance of invertebrate fossils in bulk samples from the study area. Abbreviations: $\mathrm{R}-$ rare (1-3 specimens), $\mathrm{S}-\mathrm{sparse}$ (4-10), $\mathrm{C}-$ common (11-20), F - frequent (21-100), and VF - very frequent (> 100), + - shell fragments, ? - doubtful occurrence, (m) - mold, * - autochthonous or parautochthonous. All other macrofossils are considered to be allochthonous. Notes: (a) mm-sized paucispiral operculum that is subcircular and concavo-convex in shape, (b) mm-sized oligogyrous operculum that is oval and slightly concavo-convex. Samples: 1 - R90/13, 2 - R90/14, 3 - R90/15, 4 - R90/35, 5 - R90/17, 6 - 19/89, 7 - 20/89, 8 - R90/41, 9 - R90/27, 10 - R90/11, 11 - R90/20, 12 - R90/21, 13 - 98556, 14 - 13/89, 15 - 11/89, 16 $12 / 89,17-14 / 89,18-15 / 89,19-16 / 89$.

\begin{tabular}{|c|c|c|c|c|c|c|c|c|c|c|c|c|c|c|c|c|c|c|c|}
\hline & \multirow{2}{*}{$\begin{array}{c}\mathrm{A} \\
1\end{array}$} & \multirow{2}{*}{$\begin{array}{l}\mathrm{A} \\
2 \\
\end{array}$} & \multirow{2}{*}{$\begin{array}{c}\mathrm{A} \\
3\end{array}$} & \multirow{2}{*}{$\begin{array}{l}\mathrm{A} \\
4\end{array}$} & \multirow{2}{*}{$\begin{array}{c}\mathrm{A} \\
5\end{array}$} & \multirow{2}{*}{$\begin{array}{c}\mathrm{D} \\
6\end{array}$} & \multirow{2}{*}{$\begin{array}{l}\mathrm{D} \\
7\end{array}$} & \multirow{2}{*}{$\begin{array}{l}\mathrm{D} \\
8\end{array}$} & & $\mathrm{E}$ & $\mathrm{E}$ & $\mathrm{E}$ & $\mathrm{E}$ & $\mathrm{E}$ & $\mathrm{E}$ & $\mathrm{E}$ & $\mathrm{E}$ & $\mathrm{E}$ & $\mathrm{E}$ \\
\hline & & & & & & & & & 9 & 10 & 11 & 12 & 13 & 14 & 15 & 16 & 17 & 18 & 19 \\
\hline Brachiopoda & - & - & - & - & - & - & - & - & - & - & - & - & - & - & - & - & - & - & - \\
\hline Argyrotheca cordata & $\mathrm{F}^{*}$ & - & $\mathrm{S}+$ & $\mathrm{S}+*$ & $\mathrm{C}$ & $\mathrm{S}+$ & - & $\mathrm{R}$ & - & - & $\mathrm{R}$ & - & $\mathrm{R}$ & - & $\mathrm{S}$ & - & $\mathrm{S}+$ & - & $\mathrm{S}+$ \\
\hline Argyrotheca cuneata & $\mathrm{C}^{*}$ & - & $\mathrm{S}$ & $\mathrm{C}^{*}$ & - & $\mathrm{S}$ & $\mathrm{R}$ & - & - & - & - & - & - & - & - & - & ?R & - & - \\
\hline Megathiris detruncata & $\mathrm{VF}+*$ & $\mathrm{~S}$ & $\mathrm{~F}+$ & $\mathrm{VF}+*$ & $\mathrm{C}$ & $\mathrm{C}$ & $\mathrm{R}+$ & - & $?+$ & $\mathrm{S}$ & S & $\mathrm{S}$ & $\mathrm{R}$ & - & $\mathrm{C}$ & $\mathrm{R}$ & $\mathrm{F}+$ & $\mathrm{R}$ & $\mathrm{C}+$ \\
\hline Megerlia truncata & $\mathrm{S}+*$ & - & - & $\mathrm{F}+*$ & $\mathrm{R}+$ & + & - & - & - & $\mathrm{R}$ & - & - & - & - & - & - & - & - & ?R \\
\hline Novocrania anomala & $\mathrm{C}+$ & + & - & $\mathrm{C}+$ & $\mathrm{R}+$ & $\mathrm{R}+$ & - & ?R & - & $\mathrm{R}$ & ?R & - & $\mathrm{R}$ & $\mathrm{R}$ & ?R & $\mathrm{R}$ & $\mathrm{S}+$ & $\mathrm{R}$ & - \\
\hline Terebratulid sp. & - & - & - & - & $\mathrm{R}$ & - & - & - & - & - & $\mathrm{R}$ & - & $\mathrm{R}$ & - & $\mathrm{R}+$ & - & $\mathrm{R}$ & - & - \\
\hline Gastropoda & - & - & - & - & - & - & - & - & - & - & - & - & - & - & - & - & - & - & - \\
\hline Alvania spp. & - & - & - & - & - & - & - & S & - & - & - & - & $\mathrm{S}$ & - & $\mathrm{R}+$ & - & ?R & $\mathrm{R}+$ & - \\
\hline Astraea rugosa & - & - & - & - & - & - & - & - & - & - & - & - & $\mathrm{R}$ & - & - & - & - & - & - \\
\hline Bittium reticulatum & - & - & - & - & - & - & - & S & - & - & - & - & $\mathrm{S}$ & - & $\mathrm{S}+$ & ?R & $\mathrm{VF}+$ & $? \mathrm{R},+$ & - \\
\hline Caecum trachea & - & - & - & - & - & - & - & - & - & - & - & - & - & - & - & - & $\mathrm{R}+$ & - & - \\
\hline Calliostoma granulatum & - & - & - & - & - & - & - & - & - & - & - & - & - & - & - & - & $\mathrm{R}$ & - & - \\
\hline Calliostoma zizyphinum & - & - & - & - & - & - & - & - & - & - & - & - & - & - & - & - & $\mathrm{F}+$ & - & - \\
\hline Cerithiopsis tubercularis & - & - & - & - & - & - & - & - & - & - & - & - & - & - & - & - & $\mathrm{R}$ & - & - \\
\hline Cingula sp. & - & - & - & - & - & - & - & $\mathrm{R}$ & - & - & - & - & - & - & - & - & - & - & - \\
\hline Clanculus corallinus & - & - & - & - & - & - & - & $\mathrm{R}$ & - & - & - & - & - & - & - & - & $\mathrm{S}+$ & - & - \\
\hline Clelandella miliaris & - & - & - & - & - & - & - & - & - & - & - & - & - & - & - & - & $\mathrm{R}$ & ?R & - \\
\hline Conus sp. & - & - & - & - & - & - & - & $\mathrm{R}$ & - & - & - & - & - & - & - & - & - & - & - \\
\hline Cyclope neritea & - & - & - & - & - & - & - & $\mathrm{S}$ & - & - & - & - & - & - & - & - & - & - & - \\
\hline Diodora graeca & - & - & - & - & - & - & - & - & $\mathrm{R}$ & - & - & - & $\mathrm{R}$ & - & - & - & - & - & - \\
\hline Emarginula sp. & - & - & - & - & - & - & - & - & - & - & - & - & - & - & - & - & $\mathrm{R}$ & - & - \\
\hline Epitonium clathratulum? & - & - & - & - & + & - & - & - & - & - & - & - & - & - & - & - & - & - & + \\
\hline Epitonium clathrus? & - & - & - & + & - & - & - & - & - & - & - & - & - & - & - & - & - & - & + \\
\hline Gibbula cineraria? & - & - & - & - & - & - & - & $\mathrm{S}$ & - & - & - & - & $\mathrm{R}$ & - & - & - & - & - & - \\
\hline Gibbula guttadauri & - & - & - & - & - & - & - & - & - & - & - & - & - & - & - & - & $\mathrm{R}$ & - & - \\
\hline Gibbula umbilicaris & - & - & - & - & - & - & - & $\mathrm{S}$ & - & - & ?R & - & - & - & - & - &,$+ \mathrm{C}$ & - & - \\
\hline Gibbula varia & - & - & - & - & - & - & - & - & - & - & - & - & - & - & - & - &,$+ \mathrm{F}$ & - & - \\
\hline Gourmya vulgata & - & - & - & - & - & - & - & $\mathrm{R}$ & - & - & - & - & - & - & - & - & $\mathrm{R}+$ & ?+ & - \\
\hline Haliotis tuberculata lamellosa & - & - & - & - & - & - & - & - & - & - & - & - & - & - & - & - & $?+, \mathrm{R}$ & - & - \\
\hline Homalopoma sanguineum & - & - & - & - & - & - & - & $\mathrm{R}$ & $\mathrm{R}$ & - & - & - & $\mathrm{C}$ & - & - & - & $\mathrm{F}+$ & - & - \\
\hline Jujubinus exasperatus & - & - & - & - & - & - & - & $\mathrm{S}$ & - & - & - & - & - & - & - & - & - & - & - \\
\hline Littorina sp. & - & - & - & - & - & - & - & $\mathrm{R}$ & - & - & - & - & - & - & - & - & - & - & - \\
\hline Lunatia sp. & - & - & - & - & - & - & - & $\mathrm{R}$ & - & - & - & - & ?R & - & - & - & $\mathrm{S}$ & - & - \\
\hline Mesalia brevialis & - & - & - & - & - & - & - & ?R & - & - & - & - & - & - & ?R & - & $\mathrm{S}+$ & - & - \\
\hline Mitra sp. & - & - & - & - & - & - & - & - & - & - & - & - & $\mathrm{R}$ & - & - & - & $\mathrm{R}$ & - & - \\
\hline Muricopsis cristatus & - & - & - & - & - & - & - & - & - & - & - & - & $\mathrm{R}$ & - & - & - & - & - & - \\
\hline Naticid sp. & - & - & - & - & - & - & - & $\mathrm{S}$ & - & - & - & - & - & - & - & - & - & - & - \\
\hline Odostomia sp. & - & - & - & - & - & - & - & $\mathrm{R}$ & - & - & - & - & - & - & - & - & - & - & - \\
\hline Patella caerulea & - & - & - & - & - & - & - & - & - & - & - & - & $\mathrm{R}$ & - & ?R & - & - & - & - \\
\hline Raphitoma sp. & - & - & - & - & - & - & - & $\mathrm{R}$ & - & - & - & - & $\mathrm{R}$ & - & - & - & $\mathrm{R}$ & - & - \\
\hline Retusa truncatula & - & - & - & - & - & - & - & - & $\mathrm{R}$ & - & - & - & $\mathrm{R}$ & - & - & - & ?R & - & - \\
\hline Ringicula ventricosa & - & - & - & - & - & - & - & $\mathrm{R}$ & - & - & - & - & $\mathrm{R}$ & - & - & - & $?+$ & ?R & - \\
\hline Rissoa spp. & - & - & - & - & - & - & - & - & - & - & - & - & $\mathrm{R}$ & - & - & - & $\mathrm{R}$ & - & - \\
\hline Tornus cf. Subcarinatus & - & - & - & - & - & - & - & $\mathrm{R}$ & - & - & - & - & $\mathrm{R}$ & - & - & - & $\mathrm{S}$ & - & - \\
\hline Tricolia sp. & - & - & - & - & - & - & - & - & - & - & - & - & $\mathrm{R}$ & - & - & - & - & - & - \\
\hline Triphora adversa & - & - & - & - & - & - & - & $\mathrm{R}$ & - & - & - & - & $\mathrm{R}$ & - & - & - & $?+, \mathrm{S}$ & - & - \\
\hline Turbonilla sp. & - & - & - & - & - & - & - & $\mathrm{R}$ & - & - & - & - & $\mathrm{R}$ & - & - & - & $\mathrm{S}$ & - & - \\
\hline Turritella communis & - & - & - & - & - & - & - & - & - & - & - & - & - & - & - & - & $\mathrm{R}$ & - & - \\
\hline Clio pyramidata & - & - & - & $\mathrm{R}(\mathrm{m})$ & - & - & $\mathrm{R}(\mathrm{m})$ & - & - & $\mathrm{R}(\mathrm{m})$ & - & - & - & - & - & - & - & - & - \\
\hline Operculum type 1 (a) & S & - & - & $\mathrm{F}$ & $\mathrm{S}$ & S & $\mathrm{R}$ & $\mathrm{R}$ & $\mathrm{R}$ & - & $\mathrm{F}$ & - & $\mathrm{R}$ & - & - & $S$ & $\mathrm{~F}+$ & S & - \\
\hline Operculum type 2 (b) & - & - & - & - & - & - & - & - & - & - & $\mathrm{R}$ & - & - & - & - & - & - & - & - \\
\hline Bivalvia & - & - & - & - & - & - & - & - & - & - & - & - & - & - & - & - & - & - & - \\
\hline Aequipecten opercularis & - & - & $\mathrm{R}+$ & $\mathrm{R}$ & - & - & $\mathrm{R}$ & ?R & - & - & - & - & - & - & - & - & - & $?+$ &,$+ \mathrm{R}$ \\
\hline Anomia ephippium & - & - & $\mathrm{C}+$ & $\mathrm{R}$ & - & - & - & ?R & - & $\mathrm{R}$ & $?+, \mathrm{R}$ & - & - & - & - & - & $\mathrm{R}$ & $?+, \mathrm{R}$ & $\mathrm{R}+$ \\
\hline Arca noae & - & - & - & - & - & - & - & - & - & - & - & - & - & - & - & - & $\mathrm{R}$ & - & - \\
\hline
\end{tabular}


Table 1, continued.

\begin{tabular}{|c|c|c|c|c|c|c|c|c|c|c|c|c|c|c|c|c|c|c|c|}
\hline \multirow{2}{*}{ Taxa } & \multirow{2}{*}{$\begin{array}{c}\mathrm{A} \\
1 \\
\end{array}$} & \multirow{2}{*}{$\begin{array}{c}\mathrm{A} \\
2 \\
\end{array}$} & \multirow{2}{*}{$\begin{array}{c}\mathrm{A} \\
3 \\
\end{array}$} & \multirow{2}{*}{$\begin{array}{l}\mathrm{A} \\
4 \\
\end{array}$} & \multirow{2}{*}{$\begin{array}{c}\mathrm{A} \\
5 \\
\end{array}$} & \multirow{2}{*}{$\begin{array}{l}\mathrm{D} \\
6 \\
\end{array}$} & & $\mathrm{D}$ & $\mathrm{E}$ & $\mathrm{E}$ & $\mathrm{E}$ & $\mathrm{E}$ & $\mathrm{E}$ & $\mathrm{E}$ & $\mathrm{E}$ & $\mathrm{E}$ & $\mathrm{E}$ & $\mathrm{E}$ & $E$ \\
\hline & & & & & & & 7 & 8 & 9 & 10 & 11 & 12 & 13 & 14 & 15 & 16 & 17 & 18 & 19 \\
\hline Arca tetragona & - & - & - & - & - & - & - & - & - & - & - & - & - & - & - & - & $\mathrm{C}$ & - & - \\
\hline Astarte sulcata & - & - & - & - & - & - & - & - & - & - & - & - & $\mathrm{R}$ & - & - & - & - & - & - \\
\hline Astarte triangularis & - & - & - & - & - & - & - & $\mathrm{R}$ & - & - & - & - & $\mathrm{R}$ & - & - & - & S & - & - \\
\hline Barbatia barbata & - & - & - & - & - & - & - & $\mathrm{S}$ & - & - & - & - & $\mathrm{R}$ & - & - & - & - & - & - \\
\hline Bathyarca sp. & - & - & - & - & - & - & - & - & - & - & - & - & - & - & - & - & $\mathrm{R}$ & - & - \\
\hline Callista chione & - & - & - & - & - & - & - & $\mathrm{S}$ & - & - & - & - & $\mathrm{R}$ & - & - & - & $\mathrm{R}$ & - & - \\
\hline Chlamys multistriata & + & - & S+ & $\mathrm{R}+$ & + & + & - & - & + & $\mathrm{R}$ & $\mathrm{R}+$ & - & + & + & - & + & $\mathrm{S}+$ & - & $\mathrm{R}+$ \\
\hline Chlamys varia & $\mathrm{R}$ & - & $\mathrm{R}+$ & + & - & - & - & - & - & - & + & - & - & - & - & $\mathrm{R}$ & $?+$ & - & $\mathrm{R}+$ \\
\hline Corbula gibba & - & - & - & - & - & - & - & - & - & - & - & - & $\mathrm{R}$ & - & - & - & $\mathrm{R}$ & - & - \\
\hline Crenella sp. & - & - & - & - & - & - & - & - & - & - & - & - & - & - & - & - & $\mathrm{R}$ & - & - \\
\hline Divaricella divaricata & - & - & - & - & - & - & - & $\mathrm{S}$ & - & - & - & - & - & - & - & - & $\mathrm{C}$ & - & - \\
\hline Dosinia exoleta & - & - & - & - & - & - & - & - & - & - & - & - & - & - & - & - & $\mathrm{R}$ & - & - \\
\hline Ervilia castanea & - & - & - & - & $?+$ & - & - & ?S & $\mathrm{R}$ & - &,$+ \mathrm{F}$ & - & ?S & - & + & - & $\mathrm{VF}+$ & - & - \\
\hline Gari sp. & - & - & - & - & - & - & - & - & - & - & - & - & - & - & - & - & $\mathrm{R}$ & - & - \\
\hline Glycymeris glycymeris & - & - & - & - & - & - & - & ?R & - & - & ?R & - & ? R & - & - & - & ?S & - & - \\
\hline Glycymeris violacescens & - & - & - & - & - & - & - & - & - & - & - & - & $\mathrm{R}$ & - & - & - & ?R & - & - \\
\hline Gonilia calliglypta & - & - & - & - & - & - & - & - & - & - & - & - & - & - & - & - & $\mathrm{R}$ & - & - \\
\hline Hiatella arctica & - & - & - & - & - & - & - & $\mathrm{R}$ & - & - & - & - & - & - & - & - & $\mathrm{F}+$ & - & - \\
\hline Kelliella miliaris & - & - & - & - & - & - & - & - & - & - & - & - & - & - & - & - & S & - & - \\
\hline Limatula sp. & + & - & + & + & $\mathrm{R}+$ & - & - & - & - & - & $\mathrm{R}+$ & - & - & - & - & - & $\mathrm{R}$ & - & $\mathrm{R}$ \\
\hline Limopsis sp. & - & - & - & - & - & - & - & - & - & - & - & - & - & - & - & - & $\mathrm{S}$ & - & - \\
\hline Modiolus sp. & - & - & - & - & - & - & - & ?R & - & - & - & - & - & - & - & - & S & - & - \\
\hline Myrtea spinifera & - & - & - & - & - & - & - & - & - & - & - & - & $\mathrm{R}$ & - & - & - & - & - & - \\
\hline Mysella sp. & - & - & - & - & - & - & - & - & - & - & - & - & - & - & - & - & $\mathrm{S}$ & - & - \\
\hline Notolimea crassa & - & - & - & - & - & - & - & - & - & - & - & - & - & - & - & - & $\mathrm{S}+$ & - & - \\
\hline Nucula sulcata & - & - & - & ?R & - & - & - & - & - & - & - & - & - & - & - & - & $\mathrm{R}$ & - & - \\
\hline Nuculana pella & - & - & - & - & - & - & - & - & - & - & - & - & $\mathrm{R}$ & - & - & - & - & - & - \\
\hline Ostrea edulis & S & - & $\mathrm{F}+$ & $\mathrm{C}+$ & $\mathrm{R}$ & $\mathrm{S}$ & $\mathrm{S}$ & - & - & $?+, \mathrm{R}$ &,$+ \mathrm{R}$ & - & - & $\mathrm{R}$ & $?+$ & - & $?+$ & $\mathrm{R}$ & $?+$ \\
\hline Ostrea lamellosa? & - & - & - & ?R & - & - & - & - & - & - & - & - & - & - & - & - & $?+$ & - & $?+$ \\
\hline Palliolum similis & - & - & $\mathrm{S}+$ & + & - & - & $\mathrm{R}$ & - & - & - & - & - & - & - & - & - & - & - & - \\
\hline Palliolum striatus & + & $\mathrm{R}$ & $\mathrm{S}+$ & $\mathrm{R}+$ & - & - & - & - & - & - & - & - & - & - & - & - & - & - & - \\
\hline Parvicardium papillosum & - & - & - & - & - & - & - & - & - & - & - & - & - & - & - & - & $\mathrm{R}$ & - & - \\
\hline Pecten jacobaeus & - & - & + & $\mathrm{R}+$ & + & - & - & - & - & + & $\mathrm{R}+$ & - & + & - & - & - & - & - & $\mathrm{R}+$ \\
\hline Pododesmus squama & S & $\mathrm{R}$ & $\mathrm{F}+$ & $\mathrm{S}$ & $\mathrm{S}+$ & $\mathrm{S}$ & $\mathrm{R}$ & - & - & - & $? \mathrm{~S}$ & - & - & - & - & - & $\mathrm{S}$ & - & $\mathrm{R}+$ \\
\hline Propeamussium fenestratum & - & - & + & $?+$ & - & - & - & - & - & - & - & - & - & - & - & - & $\mathrm{R}$ & - & - \\
\hline Spinula exisa & - & - & - & - & - & - & - & - & - & - & - & - & - & - & - & - & $\mathrm{C}+$ & - & - \\
\hline Spisula subtruncata & - & - & - & - & - & - & - & $S$ & - & - & - & - & $\mathrm{R}$ & - & - & - & A & - & - \\
\hline Spondylus gaederopus & - & - & - & - & - & - & - & - & + & - & $?+$ & - & - & - & - & - & ?R & - & + \\
\hline Striarca lactea & - & - & - & - & - & - & - & - & - & - & - & - & $\mathrm{R}$ & - & - & - & $?+, \mathrm{C}$ & - & - \\
\hline Tellina pygmaea & - & - & - & - & - & - & - & $\mathrm{R}$ & - & - & - & - & - & - & - & - & $\mathrm{F}$ & - & - \\
\hline Thracia sp. & - & - & - & - & - & - & - & - & - & - & - & - & - & - & - & - & $\mathrm{R}$ & - & - \\
\hline Timoclea ovata & - & - & - & - & - & - & - & $\mathrm{S}$ & - & - & $\mathrm{R}$ & - & $\mathrm{S}$ & - & - & - & $\mathrm{VF}+$ & - & - \\
\hline Venericardia sp. & - & - & - & - & - & - & - & - & - & - & - & - & $\mathrm{R}$ & - & - & - & $\mathrm{S}$ & - & - \\
\hline Venerupis rhomboides & - & - & - & - & - & - & - & $\mathrm{R}$ & - & - & - & - & - & - & - & - & - & - & - \\
\hline Venus (Chamelea) striatula & - & - & - & - & - & - & - & $\mathrm{R}$ & - & - & - & - & ?R & - & - & - & $? \mathrm{~S}$ & - & - \\
\hline Scaphopoda & - & - & - & - & - & - & - & - & - & - & - & - & - & - & - & - & - & - & - \\
\hline Dentalium dentalis? & - & - & - & - & - & - & - & - & - & - & - & - & + & - & - & - & + & - & - \\
\hline Siphonodentalium lofotense & - & - & - & - & - & - & - & - & - & - & - & - & - & - & - & - & $\mathrm{R}$ & - & - \\
\hline Polyplacophora & - & - & - & - & - & - & - & - & - & - & - & - & - & - & - & - & - & & - \\
\hline Polyplacophora indet. & - & - & - & - & - & - & - & - & - & - & - & - & $\mathrm{R}$ & - & - & - & S & - & - \\
\hline Scleractinia & - & - & - & - & - & - & - & - & & - & - & - & - & - & - & - & - & - & - \\
\hline Lophelia pertusa & - & - & - & - & - & - & - & - & - & - & - & - & - & - & - & - & $\mathrm{R}+$ & - & - \\
\hline Serpulida & - & - & - & - & - & - & - & - & - & - & - & - & - & - & - & - & - & - & - \\
\hline Ditrupa sp. & $\mathrm{C}+$ & $\mathrm{C}+$ & $\mathrm{C}$ & - & $\mathrm{S}$ & - & $\mathrm{S}$ & $\mathrm{C}$ & $\mathrm{F}+$ & $\mathrm{R}$ & $\mathrm{C}+$ & $\mathrm{C}$ & & $\mathrm{C}$ & $-\mathrm{S}$ & $\mathrm{C}+$ & $\mathrm{F}+$ & $\mathrm{S}$ & $\mathrm{S}+$ \\
\hline Hydroides norvegica & $\mathrm{R}^{*}$ & - & - & $\mathrm{S}^{*}$ & - & - & $\mathrm{R}$ & - & - & - & - & - & - & - & - & - & - & - & - \\
\hline Pomatoceros sp. & - & - & - & - & - & - & - & - & - & - & - & - & - & - & - & - & $\mathrm{R}$ & - & - \\
\hline Protula sp. & - & - & - & - & - & - & - & - & - & - & - & - & - & - & - & - & $\mathrm{R}$ & - & - \\
\hline Serpula sp. & - & - & - & $\mathrm{C}$ & - & - & - & - & - & - & - & - & - & - & - & - & - & - & - \\
\hline Spirobranchus lima & - & - & - & - & - & - & - & - & - & - & - & - & - & - & - & - & $\mathrm{R}$ & - & - \\
\hline Vermiliopsis infundibulum? & - & - & - & $\mathrm{R}$ & - & - & - & - & - & - & - & - & - & - & - & - & - & - & - \\
\hline
\end{tabular}




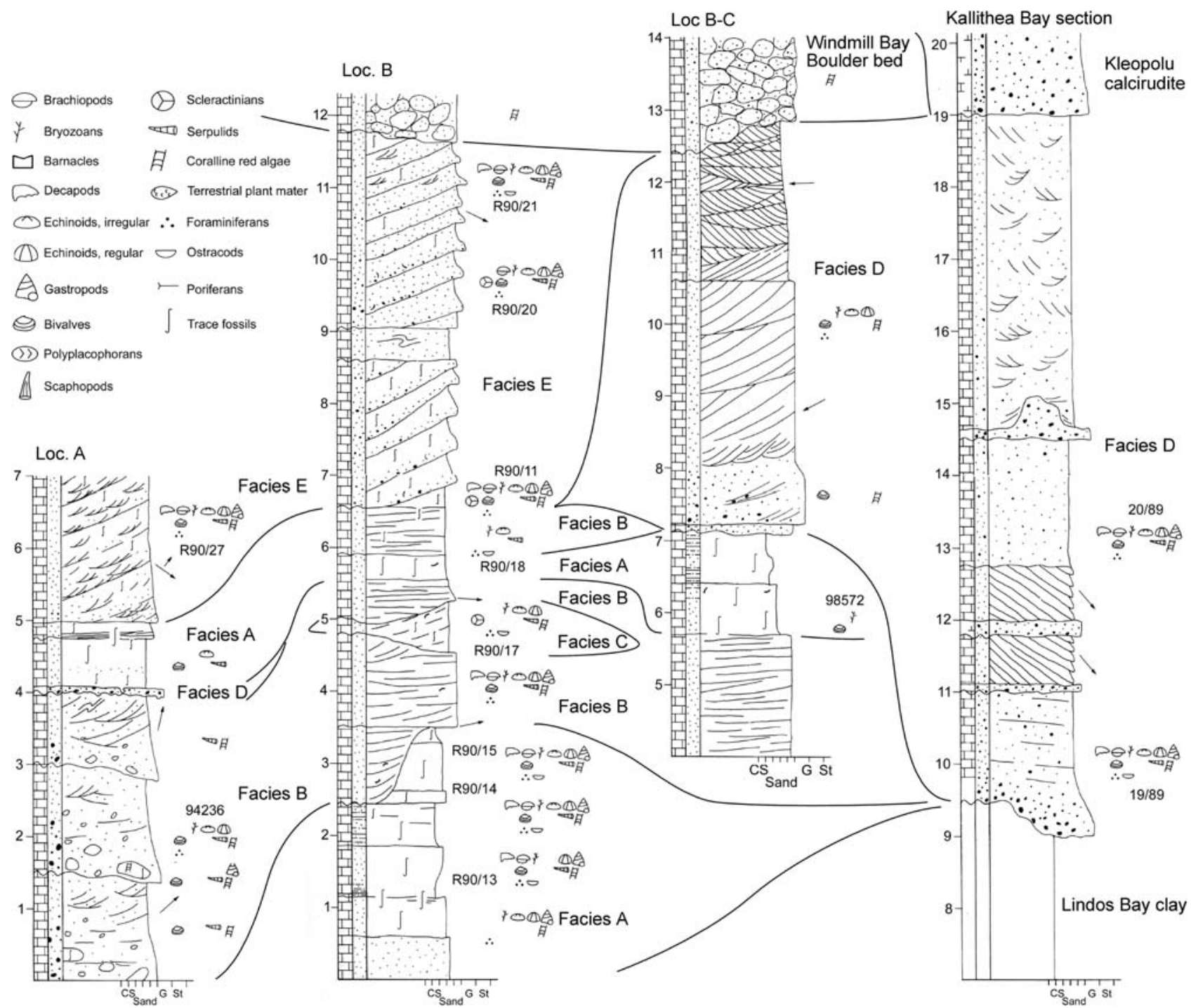

Figure 4. Sedimentological logs showing the distribution of various deposits of the Pleistocene Rhodes Formation and Lindos Acropolis Formation along with sampling sites in the southern Kallithea area. Modified from Hansen (1999).

Lower shoreface deposits of packstones, wackestones and grainstones comprise facies B, which typically includes coralline red algae, worm tubes (Ditrupa sp.), and mainly indeterminate fragments of bivalves and gastropods. Skeletal plates and spines of irregular and regular echinoids along with bryozoans also occur. The fossil content of facies $\mathrm{C}$ resembles facies B. However, the grainstones of facies $\mathrm{C}$ contain a much larger number of fragmented coralline red algae and indeterminate shells. The shell fragments are disarticulated and partly dissolved.

Disarticulated shells of endobenthic bivalves such as Callista chione and Glycymeris glycymeris are abundant in the coarse-grained sand and gravel of facies D (Fig. 7). The bivalves had a burrowing life habit and would have been capable of keeping up with an active sedimentary environ- ment. Their shells are more commonly oriented concave-up $(63 \%, \mathrm{~N}=153)$ than concave-down $(37 \%)$. The shells occur with others that are oriented obliquely and vertically. Sparse remains of irregular echinoids (e.g., Echinocyamus pusillus) may also be found.

The giant foresets (facies E) contain a faunal mixture of mainly endobenthic bivalves and epibenthic gastropods. The fossils are typically disarticulated and fragmented. Aragonitic shells may have been extensively dissolved in some gravelly levels of the foresets. A few specimens of Arctica islandica, Glycymeris glycymeris and Echinocardium cordatum have been found in life position within the Cape Arkhangelos Calcarenite (facies E; Fig. 6), between reference points $\mathrm{F}$ and $\mathrm{G}$ in Fig. 1. These were capable of keeping up with the moving sediment. Disarticulated fragments of spines and skeletal plates from regular 

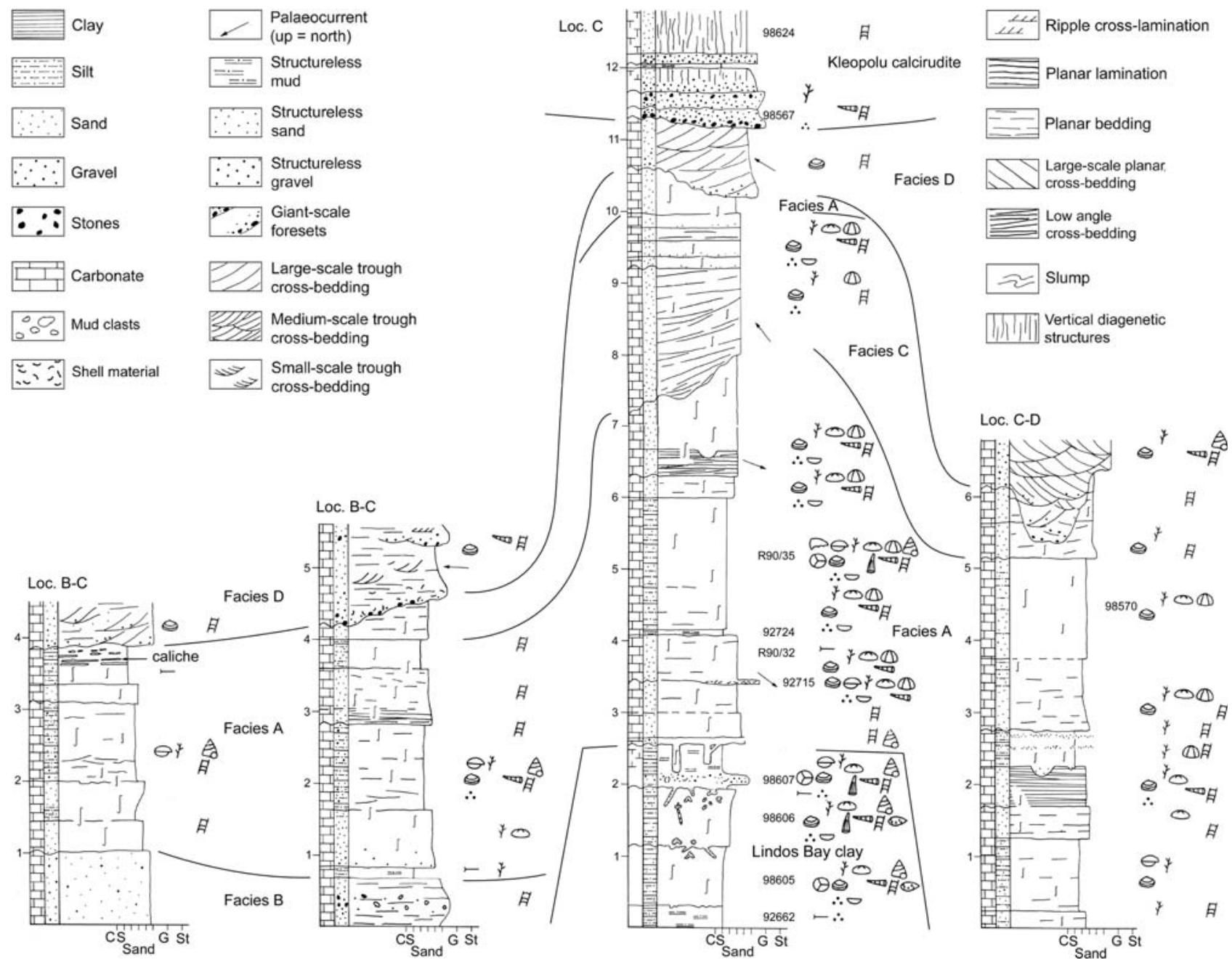

Figure 4, continued.

and irregular sea urchins (e.g., Echinocyamus pusillus) are common in the tangential giant foresets of facies E. Indeterminate shell plates from polyplacophorans are also present at this stratigraphical level.

The contact between the Mesozoic Elaphokampos Cherty Limestone and the Cape Arkhangelos Calcarenite is exposed near the northern buildings of the thermae. The karstified limestone surface was bioeroded during the initial phase of the transgression (cf. Bromley \& Asgaard 1993). The bioerosion sculpture is best preserved in a narrow zone around surviving patches of Cape Arkangelos Calcarenite deposited on the karstified and bioeroded surface. The ground rocks are dominated by borings from clionid sponges and the rock-boring bivalve Lithophaga lithophaga.

The Windmill Bay Boulder Bed consists of rounded boulders of calcite-cemented sediment. This sediment is similar to the underlying Cape Arkhangelos Calcarenite. The boulders are encrusted with coralline red algae and bryozoan colonies. Indeterminate fragments of bivalves and gastropods occur between the boulders. The Kleopolu Calcirudite also contains coralline red algae. Abraded fragments of these algae dominate the sediment.

\section{Discussion}

\section{Biostratigraphy}

Most of the invertebrate fossils recognised in the studied area have stratigraphical ranges that are too wide to provide a detailed biostratigraphy ( $c f$. Zaccaria 1968, Dermitzakis \& Georgiades-Dikeoulia 1987, Dell'Angelo \& Forli 1995). For example, the brachiopods typically range over the past few millions of years (e.g., Logan 1979, Asgaard \& Bromley 1990, Bitner 1990). Argyrotheca cordata, A. cuneata and Megerlia truncata are recognised from the Miocene, while Novocrania anomala and Megathiris detruncata are recorded from the Eocene. Dermitzakis \& Georgiades-Dikeoulia $(1979,1984,1987)$ and Georgiades-Dikeoulia (1979) presen- 


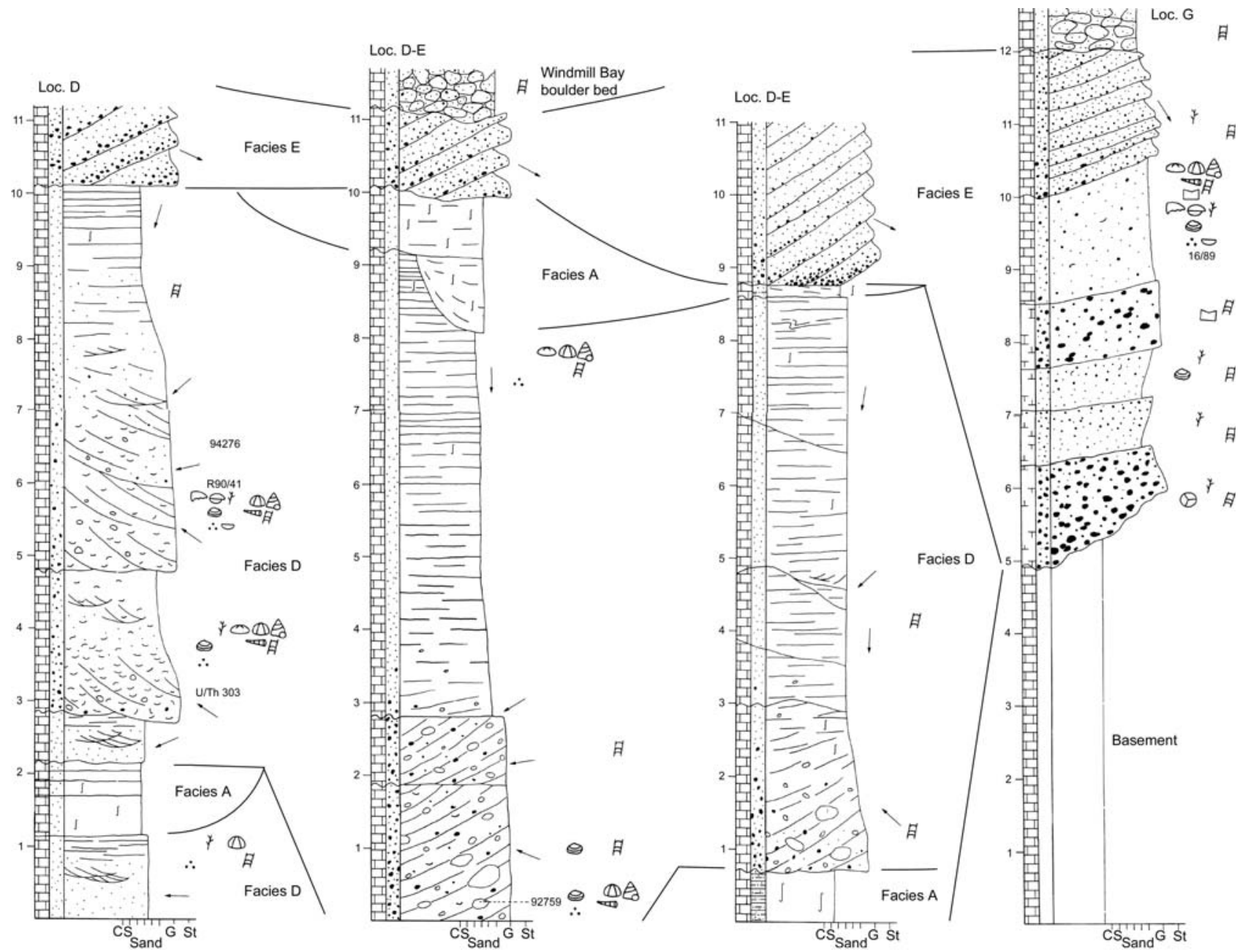

Figure 4, continued.

ted a biostratigraphy for the Hellenic region based on Miocene and Pliocene molluscan assemblages. However, in the Kallithea area, we have been unable to recognise molluscs characteristic of the Miocene and Pliocene.

The pteropods, Cavolinia tridentata and Clio pyramidata, occur in the Lindos Bay Clay in the lowest part of the Kallithea succession (Fig. 7). These species have previously been observed in Pleistocene and Holocene deposits in the Mediterranean Sea (e.g., Curry 1971, Herman 1971, 1973). Their presence suggests that the deposits at Kallithea might have formed after the Pliocene.

Three specimens of Arctica islandica have been found in life position within facies $\mathrm{E}$ of the Cape Arkhangelos Calcarenite. The first immigration of $A$. islandica into the Mediterranean Sea took place about 1.7 to 1.6 million years ago, which would correspond to the Plio-Pleistocene boundary (Benda \& Meulenkamp 1972, Raffi 1986). A. islandica is considered a "guest from the north" ("boreal guest") indicating a colder climate in the Mediterranean region (BadenPowell 1955, Orombelli \& Montanari 1967, Blanc 1968,
Keraudren 1970, Hays \& Berggren 1971, Dell'Angelo \& Forli 1995, Pasini \& Colalongo 1997, Rio et al. 1997). This bivalve was the most common northern guest in the Mediterranean Sea during the Santernian, Emilian and Sicilian (Raffi 1986). Orombelli \& Montanari (1967), and Zaccaria (1968) also regarded A. islandica as being characteristic for Mediterranean deposits of Early and Middle Pleistocene age. The global stratotype section at Vrica (Calabria, Italy) includes the base of the Pleistocene, which marks the beginning of a cold climatic phase and the first occurrence of $A$. islandica (Nikiforova \& Alekseev 1997, Pasini \& Colalongo 1997, Rio et al. 1997). The Mediterranean population of $A$. islandica became extinct 9,800 years BP (Froget et al. 1972, Raffi 1986, Dahlgren et al. 2000).

The Windmill Bay Boulder Bed and the Kleopolu Calcirudite were deposited during the Pleistocene or Holocene. However, the depositional range could not be further specified using the invertebrate fossils. The boundary between the Pleistocene and Holocene is not evident in the Kallithea area, perhaps due to insufficient biostrati- 
graphical resolution. However, the Pleistocene age of the Kallithea succession is supported by two uranium/thorium dates provided by Prof. S.-E. Lauritzen (University of Bergen). One of the dates, 108,600 BP (+ 4,000, - 3,800; ref. no. 303), was obtained from pectinid fragments collected from facies D below the clinoforms of the Cape Arkhangelos Calcarenite. The other date, 81,660 BP ( $+4,510,-4,340$; ref. no. 15-V90), came from a shell of Spondylus gaederopus collected from the Windmill Bay Boulder Bed, about $10 \mathrm{~m}$ south of the round themae building. The dates are in accordance with the stratigraphical levels of sampling. As leaching and absorption of the uranium isotopes may have occurred within the shells, the dates should be used with caution.

Some of the macrofaunal fossils that we found in the Kallithea area have previously been noted from fossiliferous Plio-Pleistocene deposits exposed along the east coast of Rhodes (e.g., Fischer 1877, Migliorini 1925, Bevilacqua 1928, Airaghi 1930, Zaccaria 1968, Keraudren 1970, Mutti et al. 1970, Broekman 1973, Sørensen 1984, Hanken et al. 1996). The biostratigraphy proposed by Zaccaria (1968), which was based on a smaller number of molluscan taxa than the present study, was established at Vasfi, Cristovasucco, and Cannamat, north of Kallithea. It indicates an Early Pleistocene age, and thereby confirms the age of the foraminiferal fauna at Vasfi, shown by Orombelli \& Montanari (1967). The Kallithea Bay section, where Pliocene and Pleistocene deposits are exposed, is

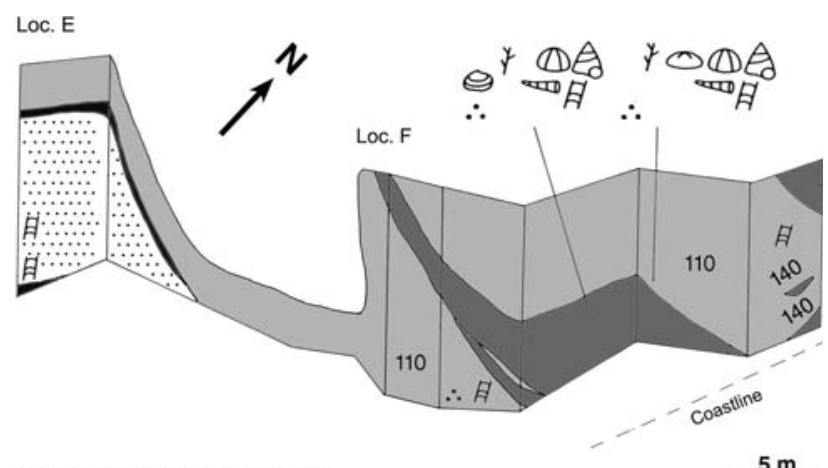

Quarry walls up to $13 \mathrm{~m}$ in height $5 \mathrm{~m}$

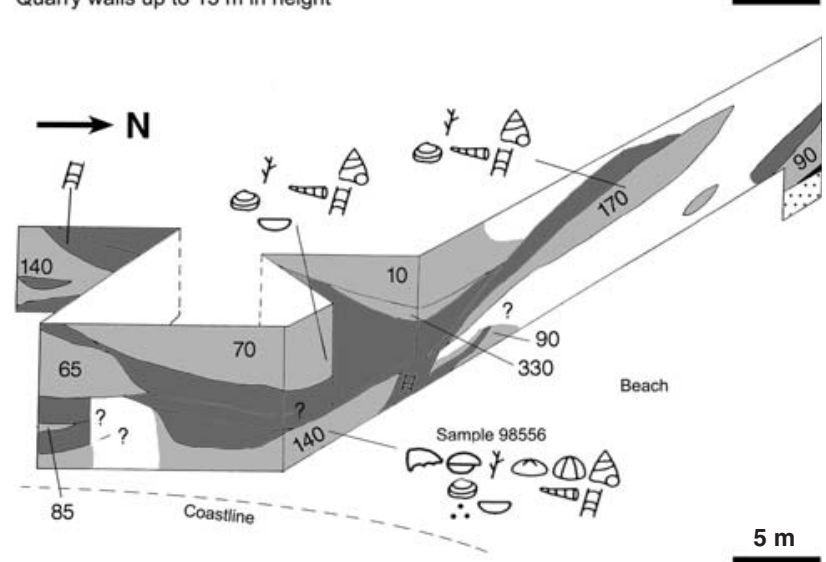
Facies $E$ (erosive scours infilled with
trough cross-bedding and HCS)

Facies $\mathrm{E}$ (giant-scale foresets) Facies $\mathrm{D}$ (trough cross-bedding and planar bedding)

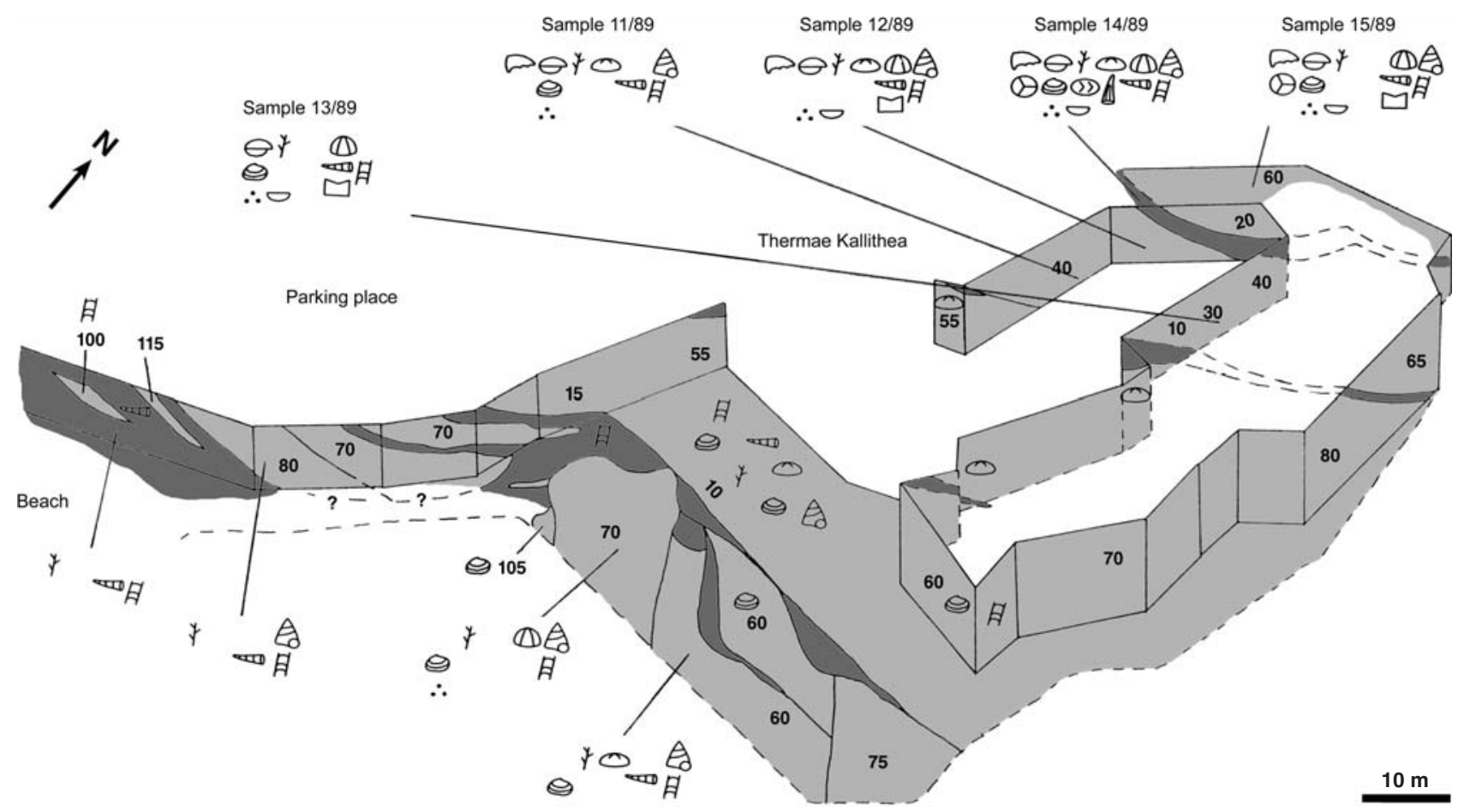

Figure 5. Fence diagrams showing the distribution of the Cape Arkhangelos Calcarenite and sampling sites in the northern Kallithea area. Although the Lindos Acropolis Formation is not shown, the facies group is up to $1 \mathrm{~m}$ in thickness and extensively overlies the Cape Arkhangelos Calcarenite. For symbols of fossils, see Fig. 4. Modified from Lønøy \& Hanken (1989) and Nielsen (1997). 
Table 2. Occurrence of invertebrate fossils in hand-picked samples. Abbreviations: ? - the presence of certain taxa, +- fragments present, ? - doubtful occurrence, * - autochthonous or parautochthonous. Other macrofossils are considered to be allochthonous. Note that sample 92724 contains sponge spicules, but none of the macrofossils included in this study. LBC - Lindos Bay Clay, CAC - Cape Arkhangelos Calcarenite. Samples: 1 - 92662,2 98605, 3 - 98606, 4 - 98607, 5 - 92715, 6 - R90/32, 7 - 98570, 8 - R90/18, 9 - 92724, 10 - 92759, 11 - 94276.

\begin{tabular}{|c|c|c|c|c|c|c|c|c|c|c|c|c|}
\hline \multirow{3}{*}{ Taxa } & \multirow[b]{2}{*}{ Facies } & \multicolumn{4}{|c|}{ LBC } & \multicolumn{7}{|c|}{$\mathrm{CAC}$} \\
\hline & & & & & & A & A & $\mathrm{A}$ & $\mathrm{A}$ & A & $\mathrm{D}$ & $\mathrm{D}$ \\
\hline & Sample & 1 & 2 & 3 & 4 & 5 & 6 & 7 & 8 & 9 & 10 & 11 \\
\hline Brachiopoda & & - & - & - & - & - & - & - & - & - & - & - \\
\hline Argyrotheca cordata & & - & - & - & $?$ & - & - & - & - & - & - & - \\
\hline Novocrania anomala & & - & - & - & - & ? & - & - & - & - & - & - \\
\hline Gastropoda & & - & - & - & - & - & - & - & - & - & - & - \\
\hline Alvania spp. & & - & - & - & - & - & - & - & - & - & $?$ & - \\
\hline Aporrhais pespelecani & & - & $\bullet *$ & •* & $\bullet *$ & - & - & - & - & - & - & - \\
\hline Astraea rugosa & & - & - & - & • & - & - & - & - & - & - & $\bullet$ \\
\hline Bittium reticulatum & & - & - & - & $?$ & - & - & - & - & - & - & - \\
\hline ?Eulimella sp. & & - & - & - & $\bullet *$ & - & - & - & - & - & - & - \\
\hline Gibbula magus & & - & - & - & $\bullet *$ & - & - & - & - & - & - & - \\
\hline Gibbula umbilicaris & & - & - & - & - & - & - & - & - & - & - & $\bullet$ \\
\hline Gourmya vulgata & & - & - & - & • & - & - & - & - & - & - & $? \bullet$ \\
\hline Jujubinus montagui & & - & - & - & $\bullet$ & - & - & - & - & - & - & - \\
\hline Jujubinus monterosatoi & & - & - & - & - & - & - & - & - & - & - & $\bullet$ \\
\hline Lunatia sp. & & - & - & - & $\bullet$ & - & - & - & - & - & - & $\bullet$ \\
\hline Nassarius limatus & & - & $\bullet *$ & $\bullet *$ & - & - & - & - & - & - & - & - \\
\hline Naticarius cruentatus? & & - & • & - & • & - & - & - & - & - & - & $\cdot$ \\
\hline Naticid spp. & & - & - & - & - & - & - & - & - & - & - & $\bullet$ \\
\hline Odostomia sp. & & - & - & - & • & - & - & - & - & - & - & - \\
\hline Phalium sp. & & - & • & - & - & - & - & - & - & - & - & - \\
\hline Philine sp. & & - & - & - & $\bullet *$ & - & - & - & - & - & - & - \\
\hline Turritella communis & & - & $\bullet *$ & •* & $\bullet *$ & - & - & - & - & - & - & - \\
\hline Turritella biplicata & & - & - & - & • & - & - & - & - & - & - & - \\
\hline Cavolinia tridentata & & - & • & - & - & - & - & - & - & - & - & - \\
\hline Clio pyramidata & & - & - & $\bullet$ & $\cdot$ & - & - & - & - & - & - & - \\
\hline Bivalvia & & - & - & - & - & - & - & - & - & - & - & $\overline{-}$ \\
\hline Abra prismatica & & - & - & - & $\bullet *$ & - & - & - & - & - & - & - \\
\hline Acanthocardia echinata & & - & - & • & $\bullet$ & - & - & - & - & - & - & - \\
\hline Acanthocardia tuberculata & & - & - & - & - & - & - & - & - & - & - & • \\
\hline Anomia ephippium & & - & - & - & $\bullet$ & - & - & - & - & - & - & - \\
\hline Callista chione & & - & - & • & $\cdot$ & - & - & - & - & - & - & - \\
\hline Cardita aculeata & & - & - & - & $\bullet *$ & - & - & - & - & - & - & - \\
\hline Chlamys multistriata & & - & - & - & - & - & - & - & - & - & - & - \\
\hline Chlamys varia & & - & - & - & $\bullet$ & • & - & - & - & - & - & $\bullet$ \\
\hline Clausinella fasciata & & - & - & - & $\bullet *$ & - & - & - & - & - & - & - \\
\hline Corbula gibba & & - & •* & •* & $\bullet *$ & - & - & - & - & - & - & - \\
\hline Cuspidaria cuspidata & & - & •* & $\bullet *$ & - & - & - & - & - & - & - & - \\
\hline Dosinia exoleta & & - & - & - & $\bullet *$ & - & - & - & - & - & - & - \\
\hline
\end{tabular}

located just south of our study area and has been described by Rasmussen et al. (2005). Migliorini (1925) mapped these deposits as possibly Quaternary in age. More recently, Rasmussen et al. (2005) showed that the deposits comprise a transgressive succession ranging from fluvial and brackish-water gravel at the base to fine-grained, deep-water marl at the top. The foraminiferans, ostracods and calcareous nannofossils in these deposits show that the brackish-water gravel probably formed during the late Pliocene, whereas the marine deposits are early Pleistocene (Rasmussen et al. 2005). As the succession of the Kallithea Bay section is stratigraphically older, their results support our aforementioned conclusions regarding the biostratigraphy. The Pleistocene age of the deposits

\begin{tabular}{|c|c|c|c|c|c|c|c|c|c|c|c|c|}
\hline \multirow{3}{*}{ Taxa } & \multirow{3}{*}{$\begin{array}{l}\text { Facies } \\
\text { Sample }\end{array}$} & \multicolumn{4}{|c|}{ LBC } & \multicolumn{7}{|c|}{$\mathrm{CAC}$} \\
\hline & & & & & & \multirow{2}{*}{$\begin{array}{l}\mathrm{A} \\
5 \\
\end{array}$} & \multirow{2}{*}{$\begin{array}{l}\text { A } \\
6 \\
\end{array}$} & \multirow{2}{*}{$\begin{array}{c}\mathrm{A} \\
7 \\
\end{array}$} & \multirow{2}{*}{$\begin{array}{l}\text { A } \\
8 \\
\end{array}$} & \multirow{2}{*}{$\frac{\mathrm{A}}{9}$} & \multirow{2}{*}{$\begin{array}{l}\mathrm{D} \\
10 \\
\end{array}$} & \multirow{2}{*}{$\begin{array}{l}\mathrm{D} \\
11 \\
\end{array}$} \\
\hline & & 1 & 2 & 3 & 4 & & & & & & & \\
\hline Ervilia castanea & & - & - & - & - & - & - & - & - & - & $?$ & $?$ \\
\hline Gari sp. & & - & - & - & •* & - & - & - & - & - & - & - \\
\hline Glossus humanus & & - & - & - & •* & - & - & - & - & - & - & - \\
\hline Glycymeris glycymeris & & - & - & - & $?$ & - & - & - & - & - & - & $\bullet$ \\
\hline Glycymeris violacescens & & - & $\bullet *$ & - & •* & - & - & - & - & - & - & • \\
\hline Hiatella arctica & & - & - & - & - & - & - & - & - & - & - & • \\
\hline Kelliella miliaris & & - & - & - & $?$ & - & - & - & - & - & - & - \\
\hline Laevicardium crassum & & - & - & - & •* & - & - & - & - & - & - & - \\
\hline Laevicardium oblongum & & - & - & - & • & - & - & - & - & - & - & - \\
\hline Myrtea spinifera & & - & •* & $\bullet *$ & •* & - & - & - & - & - & - & - \\
\hline Mysella sp. & & - & - & - & - & - & - & - & - & - & • & - \\
\hline Nucula sulcata & & - & $\bullet *$ & $\bullet *$ & $\bullet(*)$ & - & - & - & - & - & - & - \\
\hline Nuculana pella & & - & - & $?$ & - & - & - & - & - & - & - & - \\
\hline Palliolum striatus & & - & - & - & - & - & - & - & - & - & $\bullet$ & - \\
\hline Parvicardium minimum & & - & - & - & •* & - & - & - & - & - & - & - \\
\hline Parvicardium papillosum & & - & - & - & $\bullet$ & - & - & - & - & - & - & - \\
\hline Parvicardium scabrum & & - & - & - & •* & - & - & - & - & - & - & - \\
\hline Pecten jacobaeus & & - & - & - & - & - & • & - & - & - & - & • \\
\hline Peplum clavatum & & - & - & - & - & - & - & $\bullet *$ & - & - & - & - \\
\hline Pododesmus patelliformis & & - & - & - & $\bullet$ & - & - & - & - & - & - & - \\
\hline Pododesmus squama & & - & - & - & $\bullet$ & - & - & - & - & - & - & - \\
\hline Quadrans serratus & & - & $\bullet *$ & $\bullet *$ & •* & - & - & - & - & - & - & - \\
\hline Spisula subtruncata & & - & - & - & - & - & - & - & - & - & - & • \\
\hline Spondylus gaederopus & & - & - & - & - & - & - & - & - & - & - & - \\
\hline Tellina pygmaea & & - & - & - & $\bullet$ & - & - & - & - & - & - & - \\
\hline ?Thyasira sp. & & - & - & - & $\bullet *$ & - & - & - & - & - & - & - \\
\hline Timoclea ovata & & - & $\bullet *$ & $\bullet *$ & $\bullet(*)$ & - & - & - & - & - & • & - \\
\hline Venerupis rhomboides & & - & - & - & - & - & - & - & - & - & - & - \\
\hline Venus (Chamelea) striatula & & - & - & - & - & - & - & - & - & - & - & • \\
\hline Scaphopoda & & - & - & - & - & - & - & - & - & - & - & - \\
\hline Dentalium mutabile inaequi & tatum & - & $\bullet *$ & $\bullet *$ & $\bullet *$ & - & - & - & - & - & - & - \\
\hline Scleractinia & & - & - & - & - & - & - & - & - & - & - & - \\
\hline Balanophyllia europaea & & - & • & - & - & - & - & - & - & - & - & - \\
\hline Caryophyllia smithii & & - & - & - & $\bullet *$ & - & - & - & - & - & - & - \\
\hline Serpulida & & - & - & - & - & - & - & - & - & - & - & - \\
\hline Ditrupa sp. & & - & - & • & $\cdot$ & $\bullet *$ & $\cdot$ & - & $\bullet$ & - & $\bullet$ & $\bullet$ \\
\hline Serpula sp. & & - & - & - & $?$ & - & - & - & - & - & - & - \\
\hline Vermiliopsis infundibulum? & & - & - & - & $\cdot$ & - & - & - & - & - & - & - \\
\hline
\end{tabular}

within our study area concurs with the magnetic polarity stratigraphy of Løvlie et al. (1989) which shows that the Plio-Pleistocene boundary is located within the Lindos Bay Clay at Cape Vagia on the east coast of Rhodes.

\section{Biocoenoses and palaeoenvironments}

Most of the taxa collected in the Kallithea area exist in the present Mediterranean Sea (e.g., Logan 1979, Zibrowius 1980, Riedl 1983, Barash \& Danin 1988, 1992; Zenetos et al. 2005), which enables a comparison between the palaeofauna and recent biocoenoses. Pérès \& Molinier (1957), Pérès \& Picard (1964), and Pérès (1967) presented a series 
of depth zones established using recent benthic organisms in the Mediterranean Sea, viz. mediolittoral, infralittoral (down to c. $40 \mathrm{~m}$ water depth), circalittoral (40-200 m), bathyal (200-3000 m), abyssal (3000-6500 m) and hadal (>6500 m) zones. According to Pérès (1967), the distribution of substrate types, light intensity and hydrodynamic conditions are mainly responsible for the variation in benthic biocoenoses in these zones. Detailed studies of the physical and biological conditions in these zones have been conducted by Gamulin-Brida (1967), Blanc (1968), Gilat (1969) and others. With the knowledge of the ecology and distribution of recent specimens of the studied taxa, this information may be used to reconstruct palaeoenvironments and draw comparisons with similar, recent biocoenoses though not without some difficulty. The characterisation of recent biocoenoses in the infralittoral and circalittoral zones is primarily based on such organisms as seaweeds and algae (see Pérès \& Picard 1964, Picard 1965, Pérès 1967, Dounas \& Koukouras 1992), which have a very low preservation potential. Ecologically indicative taxa are therefore necessary for comparison with recent biocoenoses.

Lindos Bay Clay. - The occurrence of autochthonous and parautochthonous invertebrate fossils such as Aporrhais pespelecani, Turritella communis, Corbula gibba and Quadrans serratus (samples 98605, 98606, 98607; Nielsen 1999) indicates that the Lindos Bay Clay was deposited in the circalittoral zone (Fig. 7). These molluscs are typical of muddy deposits and were probably derived from a biocoenosis similar to the modern one of terrigenous mud (VTC) (Brambilla \& Lualdi 1988, Dell' Angelo \& Forli 1995). The latter may exist between 8 and $120 \mathrm{~m}$ water depth, most commonly at 24-95 m. However, the presence of Acanthocardia echinata, Myrtea spinifera, Laevicardium oblongum and Parvicardium papillosum indicates that the macrofauna may originate from the biocoenoses of the coastal detritic (DC) and muddy detritic bottoms (DE) (Bernasconi \& Robba 1993, Dell'Angelo \& Forli 1995). Recent specimens of the mud-related species Aporrhais pespelecani, Turritella communis and Timoclea ovata can also be found within the DC and DE biocoenoses of the Mediterranean Sea (Fig. 7). These species, which live somewhat stationary within the upper few centimetres of the muddy substrate, show that the sea bottom was characterised by fully marine conditions and well-oxygenated water. Moreover, the sedimentation rate must have been low. The consistency of the substrate was of a softground. The uppermost part of the Lindos Bay Clay contains sparse gravel lithoclasts, which enabled sedentary invertebrates like corals (sample 98607) to settle.

Abraded fragments of coralline red algae are considered to be allochthonous and were probably derived from the mediotidal and infralittoral zones (Pérès \& Picard 1964, Pérès 1967, Gamulin-Brida 1967, Blanc 1968, Bosence
1983). The presence of allochthonous terrestrial plant material indicates deposition in coastal settings, such as a protected bay. However, the occurrence of pteropods suggests open marine conditions and thus constitutes a discrepancy.

The Lindos Bay Clay in other areas has commonly been interpreted as a deep-water succession (Hanken et al. 1996). Parautochthonous bathyal bivalves have been recorded from numerous exposures of the Lindos Bay Clay along the east coast of Rhodes (e.g., Vasfi, Christovasuccio, Rodini Park, Falliraki, Kolymbia, Cape Vagia, Lindos and Pefka). The bivalves indicate deposition within the bathyal zone (Sørensen 1984). The lower part of the Lindos Bay Clay exposed at Kolymbia (Rhodes) contains ostracods suggesting depositional depths of more than $400 \mathrm{~m}$ (Hanken et al. 1996). Bryozoans indicate that parts of the type section for the Lindos Bay Clay (Lindos Bay, Rhodes) were deposited at depths of 300-500 m (Moissette \& Spjeldnaes 1995). In contrast to these previous studies, the Lindos Bay Clay in our study area holds evidence of circalittoral conditions. This occurrence therefore appears to be a local development, which, stratigraphically, may comprise the uppermost known part of the Lindos Bay Clay. Alternatively, the occurrence may be considered as redeposited sediments derived from the Lindos Bay Clay that is exposed in the Kallithea Bay section described by Rasmussen et al. (2005). However, the following arguments oppose such an interpretation: (1) Reworked mud clasts are absent in our occurrence; (2) Bathyal invertebrates that have been found in other outcrops of the Lindos Bay Clay are absent (cf. Sørensen 1984, Hanken et al. 1996); (3) Erosion of the Lindos Bay Clay forming the disconformity in the Kallithea Bay section appears to have occurred mainly after the deposition of our occurrence, within the circalittoral zone (40-200 $\mathrm{m}$ water depth). The abundance of mud clasts in the Cape Arkhangelos Calcarenite suggests that the main erosion phase of the Kallithea Bay section was contemporaneous with the formation of this facies group.

Cape Arkhangelos Calcarenite (facies A to E). - Coralline red algae occur abundantly in this facies group and probably came from a biocoenosis similar to the modern coralligenous one $(\mathrm{C})$. This is a source of coralligenous sea bottoms, typically in the circalittoral zone in areas with suitable substrates (e.g., coarse-grained sand, gravel, shells) for settlement of coralline algae. A coralligenous bottom may be up to one metre thick, mainly consisting of red algae, corals, bryozoans and serpulids. These contribute to a higher stability of the sea bottom. Over the sea bottom, the hydrodynamic energy level is high. However, the coralline red algae of the Cape Arkhangelos Calcarenite may have formed in the mediolittoral and infralittoral zones, as well as in the upper circalittoral zone (see Pérès \& Picard 1964, Bosence 1985, Basso et al. 1998, Ghosh 2002). Immigrants 


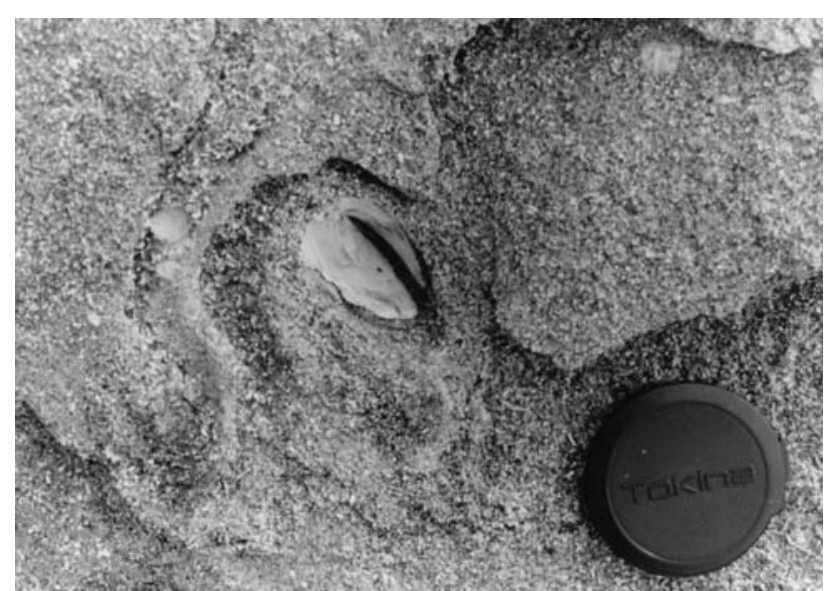

Figure 6. Arctica islandica preserved in life position in a large-scale foreset (Cape Arkhangelos Calcarenite, facies E). Camera cap $5.5 \mathrm{~cm}$ in diameter.

from a rocky bottom may colonise coralligenous bottoms (Pérès \& Picard 1964, Pérès 1967, Gamulin-Brida 1967, Luther \& Fiedler 1976). Enclaves of the coralligenous biocoenosis (C) may occur in the shadows of the vegetation of the biocoenosis of the "Posidonia" meadows (HP) (Pérès 1967). Remains of invertebrate species that commonly comprise the coralligenous biocoenosis are present in the Cape Arkhangelos Calcarenite, for example, Cerithiopsis tubercularis, Jujubinus exasperatus (Dell'Angelo \& Forli 1995), Argyrotheca cordata, A. cuneata, Megathiris detruncata and Novocrania anomala (Logan 1979; see also Logan 1983, 1988).

The macrofauna mainly contains allochthonous and parautochthonous fossils, which typically indicate normal marine conditions and deposition in the infralittoral and/or circalittoral zones. However, shells of Cyclope neritea occur in the large-scale, cross-bedded gravel of facies D (sample R90/41). This species has previously been found in Plio-Pleistocene deposits on Rhodes (Bevilacqua 1928) and is characteristic for the recent euryhaline and eurythermal biocoenoses in brackish waters (LEE) (Pérès \& Picard 1964, Pérès 1967). Cyclope neritea is common in low-saline waters (Poppe \& Goto 1991), mostly in lagoonal environments (Stolfa Zucchi 1977). This is in contrast to the records of $C$. neritea from normal marine regions such as the Mediterranean Sea, including the Aegean Sea (Forbes 1844, see Barash \& Danin 1988 for details). The macrofauna lacks other evidence of brackish conditions.
The aforementioned bioturbated wackestone of facies A (samples R90/13 and R90/35) contains parautochthonous sedentary epibenthos like brachiopods, bryozoans and serpulids that colonised hard substrates and vegetation (perhaps as detritus) on the sea bottom. The presence of these epibenthos is suggestive of environments characterised by low sedimentation rates. Recent specimens of these brachiopods typically live in the infralittoral and circalittoral zones (Table 3). The non-bioturbated tempestite beds of facies $\mathrm{A}$ are characterised by allochthonous algae and indeterminate shell fragments, indicating that the sediments may have been reworked numerous times before final deposition. The bivalves Aequipecten opercularis and Pecten jacobaeus occur sporadically in facies A, D and E, suggesting that the biocoenosis of the coastal detritic (DC) occurred in areas where these sediments were formed.

Macrofaunal fossils in facies A (e.g., sample R90/14) and $\mathrm{E}$ (sample 98556) may have been derived from biocoenoses equivalent to that of the recent "Posidonia" meadows (HP) or of the photophilic algae (AP) of the infralittoral zone. The latter may be enclaves within the biocoenosis of the "Posidonia" meadows. The epibenthos may have lived on the vegetation (see Pérès 1967, Gamulin-Brida 1967, Fornos \& Ahr 1997). The gastropods Bittium reticulatum, Diodora graeca and Gibbula guttadauri may be found in both biocoenoses. The biocoenosis of the "Posidonia" meadows (HP) may contain Cerithium vulgatum and Jujubinus exasperatus, whereas that of the photophilic algae (AP) can have Barbatia barbata and Chlamys varia (Brambilla \& Lualdi 1988, Dell'Angelo \& Forli 1995). Because these molluscs may co-occur in the Cape Arkhangelos Calcarenite, both of these biocoenoses are likely to have existed in the same area.

Bivalves such as Callista chione, Glycymeris glycymeris, Spisula subtruncata and Venerupis rhomboides, found in the cross-bedded sediment of facies D, are derived from different coastal biocoenoses (Fig. 7). They colonised unconsolidated sediment in the infralittoral or upper circalittoral zones (Table 3). Recent specimens of Spisula subtruncata preferably live in the biocoenosis of finegrained, well-sorted sand (SFBC) (Picard 1965, Pérès 1967, Brambilla \& Lualdi 1988, Bernasconi \& Robba 1993, Dell'Angelo \& Forli 1995). In contrast, Glycymeris glycymeris and Venerupis rhomboides originate from the biocoenosis of the coarse-grained sands and fine gravels under bottom currents (SGCF) (Dell'Angelo \& Forli

Figure 7. Various invertebrate fossils collected from the Lindos Bay Clay (LBC) and Cape Arkhangelos Calcarenite (CAC) of the Rhodes Formation at Kallithea. • A, B - Cardita aculeata (left valve) and Caryophyllia smithii (LBC, sample 98607). • C, D - Clio pyramidata (LBC, sample 98606). • E Cavolinia tridentata (LBC, sample 98605). $\bullet \mathrm{F}, \mathrm{G}-$ Corbula gibba, right valve (LBC, sample 98605). $\bullet \mathrm{H}-$ Aporrhais pespelecani (LBC, sample 98605$)$. - I, J - Timoclea ovata, right valve (LBC, sample 98605). $\bullet \mathrm{K}, \mathrm{L}-$ Corbula gibba, left valve (LBC, sample 98605). $\bullet$ M - Spisula subtruncata, left valve (CAC, facies D, sample 94274). $\bullet \mathrm{N}, \mathrm{O}-$ Cyclope neritea (CAC, facies D, sample R90/41). P, T - Callista chione, left valve (CAC, facies D, sample 94276). • Q, U - Venerupis rhomboides, left valve (CAC, facies D, R90/41). R, S - Nucula sulcata, right valve (LBC, sample 98605). V, W - Glossus humanus, left valve (LBC, sample 98607). Photographs by Jan Aagaard. 
Jan Kresten Nielsen et al. • Biostratigraphy and palaeoecology of the marine Pleistocene of Rhodes
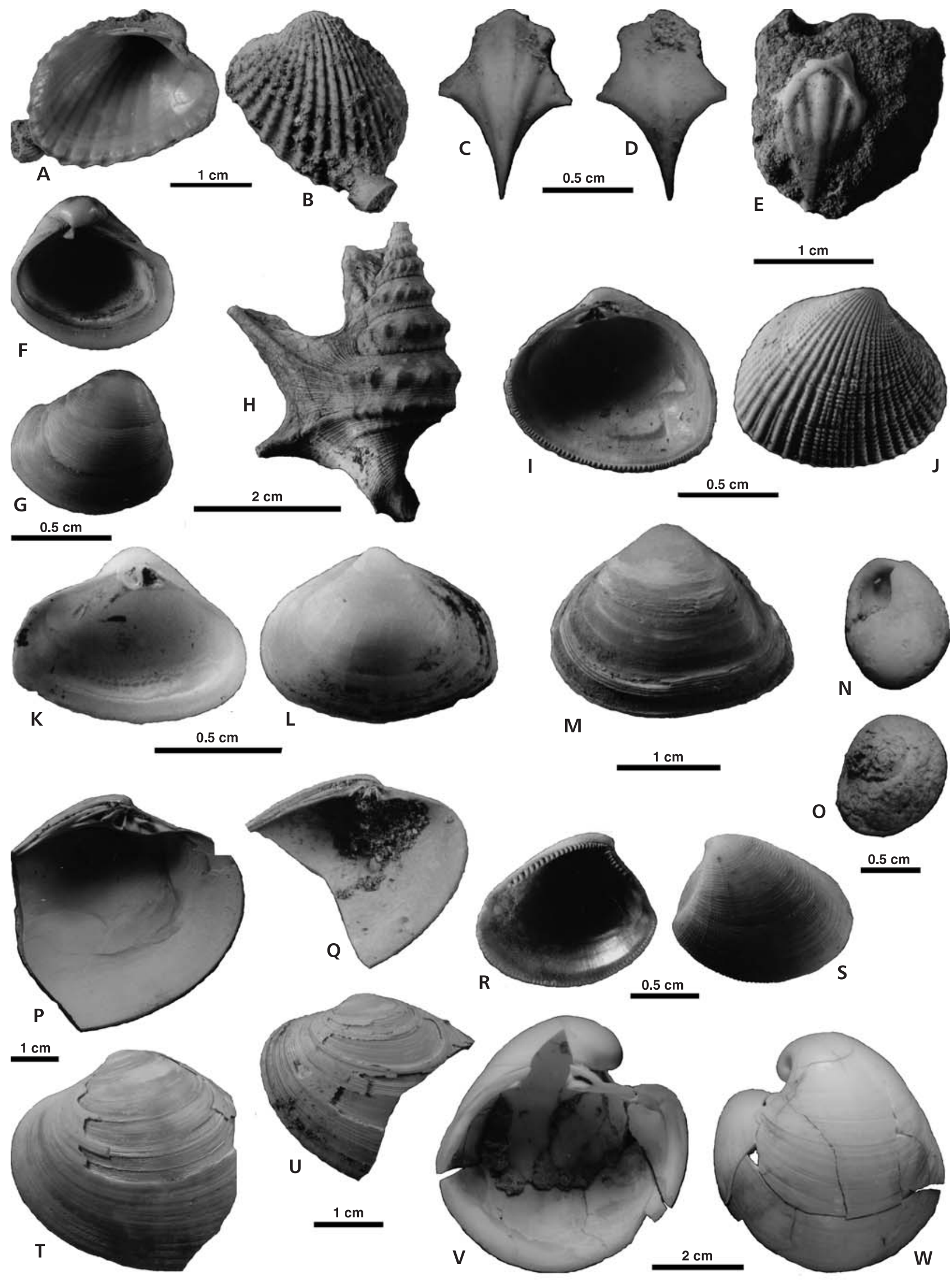
Table 3. Summary of life habits and tolerance to abiotic factors recorded for recent gastropods, bivalves, scaphopodes, scleractinians and serpulids.

\begin{tabular}{|c|c|c|c|c|c|c|c|c|c|c|}
\hline Taxa & LP & Mobility & $\begin{array}{l}\text { Trophic } \\
\text { group }\end{array}$ & Substrate & $\begin{array}{l}\text { Water depth, } \\
\text { total known range } \\
\text { (m) }\end{array}$ & $\begin{array}{l}\text { Water depth, } \\
\text { typical range } \\
\text { (m) }\end{array}$ & $\begin{array}{l}\text { Salinity, } \\
\text { normal } \\
\text { minimum } \\
(\% o)\end{array}$ & $\begin{array}{l}\text { Salinitet, } \\
\text { minimum } \\
\text { in the } \\
\text { Baltic Sea } \\
(\%)\end{array}$ & $\begin{array}{l}\text { Tempera- } \\
\text { ture } \\
\text { tolerance } \\
\left({ }^{\circ} \mathrm{C}\right) \\
\end{array}$ & $\begin{array}{l}\text { Minimum } \\
\text { summer } \\
\text { temperat. } \\
\text { open sea } \\
\left({ }^{\circ} \mathrm{C}\right) \\
\end{array}$ \\
\hline \multicolumn{11}{|l|}{ Benthic gastropods } \\
\hline Alvania spp. & E & Craw. & Her. & & & & & & & \\
\hline Aporrhais pespelecani & I & Craw., Burr. & Det., Her. & $\begin{array}{l}\text { M, Sa, MSa, MG, } \\
\text { SaM, StM, V }\end{array}$ & $4->200$ (a) & $10-150$ (a) & 19 (a) & 9 (a) & & 9? (a) \\
\hline Astraea rugosa & E & Craw. & Her. & $\mathrm{M}, \mathrm{H}, \mathrm{V}$ & MDL (b)-100 (c) & $8-50$ (d) & & & & \\
\hline ?Bela sp. & E & Craw. & Car. & & & & & & & \\
\hline Bittium reticulatum & $\mathrm{E}$ & Craw. & Car.?, Her. & $\mathrm{Sa}, \mathrm{H}, \mathrm{V}$ & MDL-250 (d) & $\begin{array}{l}0-20(\mathrm{a}) \\
0-150(\mathrm{e})\end{array}$ & 25 (a) & 12 (a) & $1-$ ? (a) & 13.5 (a) \\
\hline Caecum trachea & E & Craw. & Her. & $\mathrm{Sa}, \mathrm{SaM}, \mathrm{G}$ & $0-250$ (d) & & & & & \\
\hline Calliostoma granulatum & E & Craw. & Her. & $\mathrm{M}, \mathrm{SaM}, \mathrm{H}$ & $7-300(f)$ & & & & & \\
\hline Calliostoma zizyphinum & E & Craw. & Det., Her. & $\mathrm{M}, \mathrm{Sa}, \mathrm{H}, \mathrm{V}$ & MDL-300 (g) & $10-50$ (a) & 20 (a) & & & 13 (a) \\
\hline Cerithiopsis tubercularis & E & Craw. & Det., Car. & $\mathrm{V}$ & MDL-101 (g, h) & & & & & \\
\hline Cingula sp. & E & Craw. & Det. & $\mathrm{V}$ & & & & & & \\
\hline Clanculus corallinus & E & Craw. & Her. & $\mathrm{H}, \mathrm{V}$ & IFL-CCL(c), 5-230 (d) & SW (g) & & & & \\
\hline Clelandella miliaris & E & Craw. & Her. & $\mathrm{H}$ & $10-800$ (a) & $30-150$ (a) & 32 (a) & & & 12.5 (a) \\
\hline Conus sp. & E, I? & ? Craw., Burr.? & Car. & & & & & & & \\
\hline Cyclope neritea & $\mathrm{E}$ ? & Craw. & Car. & $\mathrm{Sa}$ & & & LS (d) & & & \\
\hline Diodora graeca & E & Craw. & Car. & $\mathrm{H}$ & $\operatorname{MDL}(\mathrm{h})-250(\mathrm{a}, \mathrm{f})$ & MDL-20 (a) & 25 (a) & & & 11 (a) \\
\hline Emarginula sp. & E & Craw. & Her.? & & & & & & & \\
\hline Epitonium clathrus & E & Craw. & Car. & $\mathrm{M}, \mathrm{Sa}$ & MDL-70 (f) & & & & & \\
\hline Epitonium clathratulum & $\mathrm{E}$ & Craw. & Car. & & & & & & & \\
\hline \multicolumn{11}{|l|}{ ?Eulimella sp. } \\
\hline Gibbula cineraria & E & Craw. & Her., Det. & $\mathrm{H}, \mathrm{V}$ & MDL-130 (a, d) & MDL-15 (a) & 25 (a) & 9 (a) & & 9? (a) \\
\hline Gibbula guttadauri & E & Craw. & Her. & & & & & & & \\
\hline Gibbula magus & $\mathrm{E}$ & Craw. & Her. & $\begin{array}{l}\text { M, MSa, SaM, } \\
\text { StM, H, V }\end{array}$ & MDL-70 (a) - >70 (d) & $\begin{array}{l}\text { MDL (a)- } \\
\text { IFL (d) }\end{array}$ & Not LS (a) & & & 12.5 (a) \\
\hline Gibbula umbilicaris & E & Craw. & Her. & $\mathrm{H}, \mathrm{V}$ & MDL-70 (a) & MDL (a) & & & & \\
\hline Gibbula varia & E & Craw. & Her. & $\mathrm{H}$ & MDL-40 (g) & & & & & \\
\hline Gourmya vulgata & E & Craw. & Her. & M, Sa, G, St, V & MDL- $>10(\mathrm{~g}, \mathrm{i})$ & & & & & \\
\hline $\begin{array}{l}\text { Haliotis tuberculata } \\
\text { lamellosa }\end{array}$ & $\mathrm{E}$ & Craw. & Her. & $\mathrm{H}$ & MDL-CCL(c) & SW (i) & & & & \\
\hline Homalopoma sanguineum & $\mathrm{E}$ & Craw. & Her. & $\mathrm{H}, \mathrm{K}, \mathrm{V}$ & MDL-50 (d) $-100(\mathrm{t})$ & & & & & \\
\hline Jujubinus exasperatus & E & Craw. & Her. & $\mathrm{M}, \mathrm{K}, \mathrm{V}$ & $0-200$ (d) & & & & & \\
\hline Jujubinus montagui & E & Craw. & Her. & $\mathrm{H}$ & $\operatorname{IFL}(\mathrm{h})$ & & & & & \\
\hline Jujubinus monterosatoi & E & Craw. & Her. & $\mathrm{K}$ & $0-40$ (c) & & & & & \\
\hline Littorina sp. & E & Craw. & Her. & & & & & & & \\
\hline Lunatia sp. & I & Burr. & Car. & & & & & & & \\
\hline Mesalia brevialis & E? & Craw. & Fil. & $\mathrm{M}, \mathrm{Sa}$ & & & & & & \\
\hline Mitra sp. & E & Craw. & Car. & & & & & & & \\
\hline Muricopsis cristatus & E & Craw. & Car. & $\mathrm{Sa}, \mathrm{H}, \mathrm{V}$ & $0-100$ (d) & & & & & \\
\hline Nassarius limatus & E & Craw. & Car. & & MDL-GD (g) & & & & & \\
\hline Naticarius cruentatus & I & Burr. & Car. & M, Sa & MDL-IFL (c) & & & & & \\
\hline Odostomia sp. & & & Par.? & & & & & & & \\
\hline Patella caerulea & E & Craw. & Her. & $\mathrm{H}$ & MDL (g)-IFL (c) & & & & & \\
\hline Phalium sp. & E & Craw. & Car. & & & & & & & \\
\hline \multicolumn{11}{|l|}{ Philine sp. } \\
\hline Raphitoma sp. & $\mathrm{E}$ & Craw. & Car. & & & & & & & \\
\hline Retusa truncatula & I & Burr. & Car. & $\mathrm{Sa}$ & $0-200$ (d) & & & & & \\
\hline Ringicula ventricosa & $\mathrm{I} ?$ & Burr.? & Car.? & & & & & & & \\
\hline Rissoa spp. & E & Craw. & Det., Her. & $\mathrm{V}$ & PZ? & & & & & \\
\hline \multicolumn{11}{|l|}{ Tornus cf. subcarinatus } \\
\hline Tricolia sp. & E & Craw. & Her. & $\mathrm{V}$ & & & & & & \\
\hline Triphora adversa & E & Craw. & Car., Det. & $\mathrm{Sa}, \mathrm{St}, \mathrm{H}, \mathrm{V}$ & SW-80 (b) (1) & & & & & \\
\hline Turbonilla sp. & E? & Craw.? & Par.? & & & & & & & \\
\hline Turritella biplicata & I & Burr. & Fil. & $\mathrm{M}, \mathrm{Sa}$ & & & & & & \\
\hline Turritella communis & I & Burr. & Fil. & $\begin{array}{l}\text { M, MSa, MG, } \\
\text { GM, StM }\end{array}$ & $10-200(a, b, e)$ & 20-100 (a) & 25 (a) & 12 (a) & & 13 (a) \\
\hline Operculum type 1 & B & & & & & & & & & \\
\hline Operculum type 2 & B & & & & & & & & & \\
\hline
\end{tabular}


Table 3, continued.

\begin{tabular}{|c|c|c|c|c|c|c|c|c|c|c|}
\hline Taxa & LP & Mobility & $\begin{array}{l}\text { Trophic } \\
\text { group }\end{array}$ & Substrate & $\begin{array}{l}\text { Water depth, } \\
\text { total known range } \\
\text { (m) }\end{array}$ & $\begin{array}{l}\text { Water depth, } \\
\text { typical range } \\
\text { (m) }\end{array}$ & $\begin{array}{l}\text { Salinity, } \\
\text { normal } \\
\text { minimum } \\
(\% o)\end{array}$ & $\begin{array}{l}\text { Salinitet, } \\
\text { minimum } \\
\text { in the } \\
\text { Baltic Sea } \\
(\% o)\end{array}$ & $\begin{array}{l}\text { Tempera- } \\
\text { ture } \\
\text { tolerance } \\
\left({ }^{\circ} \mathrm{C}\right)\end{array}$ & $\begin{array}{l}\text { Minimum } \\
\text { summer } \\
\text { temperat. } \\
\text { open sea } \\
\left({ }^{\circ} \mathrm{C}\right)\end{array}$ \\
\hline \multicolumn{11}{|l|}{ Pelagic gastropods } \\
\hline Cavolinia tridentata & $\mathrm{P}$ & Swim., Plankt. & Susp. & & & & & & & \\
\hline Clio paramidata & $\mathrm{P}$ & Swim., Plankt. & Susp. & & NSW (a) & & 35.5 (a) & & $13-28$ (a) & \\
\hline \multicolumn{11}{|l|}{ Bivalves } \\
\hline Abra prismatica & I & Burr. & Susp. & $\mathrm{M}, \mathrm{MSa}, \mathrm{Sa}$ & $0-160$ (a) -400 (n) & $0-60$ (a) & 31 (a) & 16 (a) & & 10.5 (a) \\
\hline Acanthocardia echinata & SI & Burr. & Susp. & $\mathrm{M}, \mathrm{MSa}, \mathrm{Sa}, \mathrm{G}, \mathrm{V}$ & $0-100$ (a) & $0-75$ (a) & 25 (a) & 12 (a) & $0-12$ (a) & 9 (a) \\
\hline $\begin{array}{l}\text { Acanthocardia } \\
\text { tuberculata }\end{array}$ & SI & Burr. & Susp. & $\begin{array}{l}\text { M, Sa, MSa, } \\
\text { SaM, G }\end{array}$ & $0-100$ (a) & $0-10$ (a) & & & $6-?$ (a) & 15 (a) \\
\hline Aequipecten opercularis & $\mathrm{E}$ & FL., swim. & Susp. & $\begin{array}{l}\text { M, SaM, Sa, SaG, } \\
\text { K }\end{array}$ & $\begin{array}{l}0-200(a, b)-400(s)- \\
2600(j)\end{array}$ & 0-75 (a) & 25 (a) & 12 (a) & & 13 (a) \\
\hline Anomia ephippium & $\mathrm{E}$ & Byss., Cem. & Susp. & $\mathrm{H}, \mathrm{K}, \mathrm{V}$ & $0-146$ (a) $\rightarrow 1500$ (k) & & & & & 9 (a) \\
\hline Arca noae & $\mathrm{E}$ & Byss. & Susp. & $\mathrm{H}$ & $0-119(\mathrm{n})$ & & & & & \\
\hline Arca tetragona & $\mathrm{E}$ & Byss. & Susp. & $\mathrm{H}, \mathrm{K}$ & MDL-100 (l, m) $\rightarrow>2000$ (a) & MDL-90 (a) & 34 (a) & 27 (a) & & 11.5 (a) \\
\hline Arctica islandica & I & Burr. & Susp. & $\mathrm{SaM}, \mathrm{MSa}, \mathrm{S}$ & $0-100$ (a) & & 10 (a) & & $0-20$ (a) & 8.5 (2) (a) \\
\hline Astarte sulcata & I & Burr. & Susp. & $\mathrm{M}, \mathrm{MG}, \mathrm{SaG}, \mathrm{St}$ & $6-?(1), 5-80$ (a) & & 25 (a) & 17 (a) & & 9 (a) \\
\hline Astarte triangularis & I & Burr. & Susp. & $\mathrm{SaM}, \mathrm{SaG}, \mathrm{G}$ & $10->91(\mathrm{a}, \mathrm{l})$ & & 33 (a) & & & 14.5 (a) \\
\hline Barbatia barbata & $\mathrm{E}$ & Byss. & Susp. & $\mathrm{H}$ & MDL-280 (n) & & & & & \\
\hline Bathyarca sp. & $\begin{array}{l}\mathrm{I}, \mathrm{J} \\
\mathrm{E}\end{array}$ & Byss. & Susp. & & & & & & & \\
\hline Callista chione & I & Burr. & Susp. & $\mathrm{Sa}$ & SW-128 (1) & & & & & \\
\hline Cardita aculeata & I & Burr. & Susp. & $\mathrm{M}, \mathrm{SaM}, \mathrm{H}$ & 4-1065 (u) & & & & & \\
\hline Chlamys varia & $\mathrm{E}$ & Byss., FL. & Susp. & $\mathrm{Sa}, \mathrm{H}, \mathrm{K}$ & $0-182(a)-1350(j)$ & & 27 (a) & & & 13.5 (a) \\
\hline Chlamys multistriata & $\mathrm{E}$ & Byss. & Susp. & MSa, G, H & 7-? (1), 8-2600 (u) & & & & & \\
\hline Clausinella fasciata & I & Burr. & Susp. & $\mathrm{Sa}, \mathrm{MG}, \mathrm{G}$ & $4-110$ (a) & & 32 (a) & 17 (a) & & 13 (a) \\
\hline Corbula gibba & I & Byss., Burr. & Susp. & $\begin{array}{l}\text { M, SaM, MSa } \\
\text { (with G, St), SiSa, } \\
\text { Sa, MG }\end{array}$ & MDL-100 (a) -2200 (j) & & 22 (a) & 8 (a) & & 10.5 (a) \\
\hline Crenella sp. & $\mathrm{E}$ & Byss. & Susp. & & & & & & & \\
\hline Cuspidaria cuspidata & I & Burr. & Car. & M, MSa, G & 20-? (1) 73-201 (h) & & & & & \\
\hline Divaricella divaricata & I & Burr. & Susp., Dep.? & $\mathrm{M}, \mathrm{GSa}$ & $0-40$ (i) & & & & & \\
\hline Dosinia exoleta & I & Burr. & Susp. & $\mathrm{M}, \mathrm{Sa}$ & MDL-70 (a) -100 (j) & & 28 (a) & 23 (a) & & 13 (a) \\
\hline Ervilia castanea & I & Burr. & Susp. & $\mathrm{Sa}, \mathrm{G}$ & MDL-SUL (p) & & & & & \\
\hline Gari sp. & I & Burr. & Susp. & & & & & & & \\
\hline Glossus humanus & I & Burr. & Susp. & $\mathrm{M}, \mathrm{SaM}, \mathrm{Sa}$ & 5-? (m)-CCL(c) & & & & & \\
\hline Glycymeris glycymeris & I & Burr. & Susp. & $\mathrm{M}, \mathrm{Sa}, \mathrm{MG}, \mathrm{SaG}, \mathrm{G}$ & $0-73$ (a) & 10-73 (a) & 33 (a) & & $5-?(a)$ & \\
\hline Glycymeris violacescens & I & Burr. & Susp. & $\mathrm{M}, \mathrm{MSa}, \mathrm{Sa}, \mathrm{H}$ & $\operatorname{IFL}(\mathrm{h}, \mathrm{n})$ & & & & & \\
\hline Gonilia calliglypta & I & Burr. & Susp. & & $10-200(n)$ & & & & & \\
\hline Hiatella arctica & $\mathrm{I}, \mathrm{E}$ & Bor., Byss. & Susp. & $\mathrm{H}, \mathrm{V}$ & $\begin{array}{l}\text { MDL-120 (a) }-1400 \text { (n), } \\
-1895 \text { (q) }\end{array}$ & MDL-75 (a) & 20 (a) & 11 (a) & & \\
\hline Kelliella miliaris & I & Burr. & Susp. & & $\begin{array}{l}50(\mathrm{w}), 80-1300(\mathrm{a}) \\
580-3222(\mathrm{q})\end{array}$ & $100-1000$ (a) & 33 (a) & 27 (a) & $5-?$ (a) & \\
\hline Laevicardium crassum & I & Burr. & Susp. & $\begin{array}{l}\text { M, SaM, MSa, } \\
\text { Sa, G, St }\end{array}$ & 7-185 (a) & & 25 (a) & 17 (a) & $5-? 5$ (a) & \\
\hline Laevicardium oblongum & I & Burr. & Susp. & $\mathrm{M}, \mathrm{Sa}$ & IFL-CCL(c) & & & & & \\
\hline Limatula sp. & $\mathrm{E}$ & Byss. & Susp. & & & & & & & \\
\hline Limopsis sp. & & Byss. & Susp. & & & & & & & \\
\hline Modiolus sp. & $\mathrm{E}$ & Byss. & Susp. & & & & & & & \\
\hline Myrtea spinifera & I & Burr. & $\begin{array}{l}\text { Susp., } \\
\text { Dep.? }\end{array}$ & $\begin{array}{l}\text { M, MSa, SiSa, } \\
\text { MG, K, V }\end{array}$ & $7-120$ (a) & & 33 (a) & & $6-?$ (a) & \\
\hline Mysella sp. & I & & & & & & & & & \\
\hline Notolimea crassa & $\mathrm{E}$ & Byss.? & Susp. & M, K & $55-2600(\mathrm{u})$ & & & & & \\
\hline Nucula sulcata & I & Burr. & Dep. & M, SaM, MSa, Sa & $9-180$ (a) $-220(1, h)$ & & 23 (a) & & $5-?$ (a) & 15 (a) \\
\hline Nuculana pella & I & Burr. & & $\mathrm{M}, \mathrm{SaM}, \mathrm{Sa}$ & $4-250(\mathrm{k})$ & & & & & \\
\hline $\begin{array}{l}\text { Nuculana fragilis var. } \\
\text { deltoidea }\end{array}$ & I & Burr. & & & & & & & & \\
\hline Ostrea edulis & $\mathrm{E}$ & Cem. & Susp. & $\mathrm{H}$ & $0-90(\mathrm{n})$ & $0-40$ (a) & 25 (a) & & 4-? (a) & $15-20$ (a) \\
\hline Ostrea lamellosa & $\mathrm{E}$ & Cem. & Susp. & $\mathrm{H}$ & & & & & & \\
\hline $\begin{array}{l}\text { Palliolum (Similipecten) } \\
\text { similis }\end{array}$ & $\mathrm{E}$ & Byss. & Susp. & $\mathrm{M}, \mathrm{MSa}, \mathrm{Sa}, \mathrm{G}$ & $27-1190(\mathrm{u})$ & $30-55$ (a) & 23 (a) & & $6.5-?$ (a) & \\
\hline Palliolum striatus & $\mathrm{E}$ & Byss. & Susp. & $\mathrm{M}, \mathrm{Sa}, \mathrm{H}$ & $7-800(\mathrm{~s})$ & & & & & \\
\hline Parvicardium minimum & I & Burr. & Susp. & M, MSa, G & $9-400$ (a); 580-3222 (q) & $100-150$ (a) & 25 (a) & 12 (a) & 4.5-? (a) & 8.5 (a) \\
\hline Parvicardium papillosum & I & Burr. & Susp. & $\mathrm{M}, \mathrm{Sa}, \mathrm{G}, \mathrm{K}, \mathrm{V}$ & & & & & & \\
\hline
\end{tabular}


Table 3, continued.

\begin{tabular}{|c|c|c|c|c|c|c|c|c|c|c|}
\hline Taxa & LP & Mobility & $\begin{array}{l}\text { Trophic } \\
\text { group }\end{array}$ & Substrate & $\begin{array}{l}\text { Water depth, } \\
\text { total known range } \\
\text { (m) }\end{array}$ & $\begin{array}{l}\text { Water depth, } \\
\text { typical range } \\
\text { (m) }\end{array}$ & $\begin{array}{l}\text { Salinity, } \\
\text { normal } \\
\text { minimum } \\
(\%)\end{array}$ & $\begin{array}{l}\text { Salinitet, } \\
\text { minimum } \\
\text { in the } \\
\text { Baltic Sea } \\
(\%)\end{array}$ & $\begin{array}{l}\text { Tempera- } \\
\text { ture } \\
\text { tolerance } \\
\left({ }^{\circ} \mathrm{C}\right) \\
\end{array}$ & $\begin{array}{l}\text { Minimum } \\
\text { summer } \\
\text { temperat. } \\
\text { open sea } \\
\left({ }^{\circ} \mathrm{C}\right) \\
\end{array}$ \\
\hline Parvicardium scabrum & I & Burr. & Susp. & $\mathrm{MSa}, \mathrm{G}, \mathrm{St}$ & 9-140 (a) & $16-50$ (a) & 32 (a) & 17 (a) & & 10 (a) \\
\hline Pecten jacobaeus & E & FL., swim. & Susp. & $\mathrm{M}, \mathrm{Sa}, \mathrm{G}$ & 25-183 (a) & & & & & \\
\hline Peplum clavatum & E & FL.?, swim? & Susp. & $\mathrm{Si}$ & MDL-30 (o) -1400 (s) & & & & & \\
\hline Pododesmus patelliformis & E & $\begin{array}{l}\text { Byss., Cem. } \\
\text { (i) }\end{array}$ & Susp. & $\mathrm{H}$ & $0-200$ (a) & 25-100 (a) & 25 (a) & 12 (a) & & 12.5 (a) \\
\hline Pododesmus squama & $\mathrm{E}$ & Byss., Cem. & Susp. & $\mathrm{H}$ & 7-110 (a) & & & & & \\
\hline Propeamussium fenestratum & $\imath \mathrm{E}$ & Byss. & Susp. & $\mathrm{M}, \mathrm{K}$ & $50-4000(\mathrm{n})$ & & & & & \\
\hline Quadrans serratus & I & Burr. & Det., Susp.? & M, MSa, G, K, V & 10-101 (i, h) & & & & & \\
\hline Spinula exisa & I & Burr. & Dep.? & & $1846-3000(\mathrm{u})$ & & & & & \\
\hline Spisula subtruncata & I & Burr. & Susp. & M, MSa, SiSa, Sa, & MDL-200 (n) & $0-40$ (a) & 20 (a) & 11 (a) & & 12.5 (a) \\
\hline Spondylus gaederopus & E & Cem. & Susp. & $\mathrm{H}$ & & $2-7$ (h) & & & & \\
\hline Striarca lactea & E & Byss. & Susp. & $\mathrm{H}$ & MDL-500 $(\mathrm{k}, \mathrm{l})$ & & & & & \\
\hline Tellina pygmaea & I & Burr. & Det., Susp.? & $\mathrm{Sa}, \mathrm{G}$ & LSH-? (r)-150 (m) & & & & & \\
\hline Thracia sp. & I & Burr. & Dep.? & & & & & & & \\
\hline ?Thyasira sp. & I & Burr. & & & & & & & & \\
\hline Timoclea ovata & I & Burr. & Susp. & M, MSa, Sa, G & 4-183 (1) & $30-100$ (a) & 25 (a) & 14 (a) & $3.5-?$ (a) & \\
\hline Venericardia sp. & I & Burr. & Dep.? & & & & & & & \\
\hline Venerupis rhomboides & I & Burr. & Susp. & $\mathrm{Sa}, \mathrm{MG}, \mathrm{SaG}, \mathrm{G}$ & 0-183 (1) & $0-75$ (a) & STH (a) & & & 13 (a) \\
\hline Venus (Chamelea) striatula & $\mathrm{I}$ & Burr. & Susp. & $\mathrm{M}, \mathrm{Sa}$ & MDL-380 (n) & & & & & \\
\hline \multicolumn{11}{|l|}{ Scaphopods } \\
\hline Dentalium dentalis & I & Burr. & Dep. & $\mathrm{M}, \mathrm{Sa}, \mathrm{K}$ & & $1-164(v)$ & & & & \\
\hline $\begin{array}{l}\text { Dentalium mutabile } \\
\text { inaequicostatum }\end{array}$ & I & Burr. & Dep. & M, SaM, Sa, K & $5-120(n)-128(h)$ & $5-120(v)$ & & & & \\
\hline Siphonodentalium lofotense & I & Burr. & Dep. & & ca. $100(\mathrm{v})$ & & & & & \\
\hline \multicolumn{11}{|l|}{ Brachiopods } \\
\hline Argyrotheca cordata & E & Sed. & Susp. & $\mathrm{H}$ & $0-600(y)$ & 20-60 (y) & & & & \\
\hline Argyrotheca cuneata & E & Sed. & Susp. & $\mathrm{H}$ & $0-600(y)-366(z)$ & $0-100(y)$ & & & & \\
\hline Novocrania anomala & E & Cem. & Susp. & $\mathrm{H}$ & 3-300 (y) -1484 (z) & & & & & \\
\hline Megathiris detruncata & E & Sed. & Susp. & $\mathrm{H}$ & $0-200(y)-896(z)$ & $20-160(y)$ & & & & \\
\hline Megerlia truncata & E & Sed. & Susp. & $\mathrm{H}$ & $12-300(\mathrm{y})$ & Bathyal (y) & & & & \\
\hline \multicolumn{11}{|l|}{ Scleractinians } \\
\hline Balanophyllia europaea & $\mathrm{E}$ & Cem. & Susp., Z. & $\mathrm{H}$ & IFL (aa) & & $\begin{array}{l}(28-) 32- \\
40 \text { (a) }\end{array}$ & & & \\
\hline Caryophyllia smithii & E & Cem. & Susp. & $\mathrm{M}(\operatorname{med} \mathrm{St}), \mathrm{H}$ & >10 m (x), IFL, UB (aa) & & $\begin{array}{l}(28-) 32- \\
40 \text { (a) }\end{array}$ & & & \\
\hline Lophelia pertusa & E & Cem. & Susp. & $\mathrm{H}$ & $\begin{array}{l}\text { 60-1500 (3), 230-680 (4) } \\
\text { (aa) }\end{array}$ & & $\begin{array}{l}(28-) 32- \\
40 \text { (a) }\end{array}$ & & & \\
\hline \multicolumn{11}{|l|}{ Serpulides } \\
\hline Ditrupa sp. & E & FL. & Det. & & & & & & & \\
\hline Hydroides norvegica & $\mathrm{E}$ & Cem. & Susp. & $\mathrm{H}$ & & $-50(\mathrm{bb})$ & & & & \\
\hline Pomatoceros sp. & $\mathrm{E}$ & Cem. & Susp. & $\mathrm{H}$ & & & & & & \\
\hline Protula sp. & E & Cem.? & Susp. & & & & & & & \\
\hline Serpula sp. & E & Cem. & Susp. & $\mathrm{H}, \mathrm{V}$ & & & & & & \\
\hline Spirobranchus lima & E & Cem. & Susp. & $\mathrm{H}, \mathrm{V}$ & $-50(\mathrm{bb})$ & & & & & \\
\hline Vermiliopsis infundibulum & E & Cem. & Susp. & $\mathrm{H}$ & & & & & & \\
\hline
\end{tabular}

Note that 0 m entries commonly correspond to shallow water. Abbreviations: M - mud, Si - silt, Sa - sand, G-gravel, St - stones, SaM - sandy mud, GM - gravelly mud, StM - stony mud, MSa - muddy sand, SiSa - silty sand, GSa - gravelly sand, MG - muddy gravel, SaG - sandy gravel, H - hard substrates, $\mathrm{K}$ - vegetation (coralline red algae), V - vegetation (seaweed), E - epifaunal, I - infaunal, B - benthic, S - semiinfaunal, J - juvenile, P - pelagic, Craw. - crawling, Burr. - burrowing, Plankt. - planktonic, FL. - free laying, Byss. - byssate, Cem. - cementing, Sed. - sedentary, Bor. - boring, Her. herbivore, Det. - detritus, Car. - carnivore, Fil. - filtrator, Par. - parasite, Susp. - suspension, Dep. - deposit, Z. - zooxanthellae, MDL - mediolittoral, IFL - infralittoral, CCL - circalittoral, SW - shallow water, LS - low saline, Not LS - not low salinity, GD - greater depths, PZ - photic zone, NSW - not surface water, SUL - sublittoral, LSH - lower shoreface, UB - upper bathyal, STH - stenohaline, LP - life position.

Notes: (1) Unknown whether these data are derived from specimens of T. adversa or T. perversa (see Bouchet \& Guillemots 1978 for details). (2) Maximal winter temperature for Arctica islandica is $10^{\circ} \mathrm{C}$ (a). (3) NE Atlantic Sea. (4) Mediterranean Sea.

References: (a) Peacock 1993, (b) Lellák 1978, (c) D’Angelo and Gargiullo 1981, (d) Poppe \& Goto 1991, (e) Sneli 1975, (f) Abbott 1991, (g) Nordsieck 1968, (h) Barash \& Danin 1992, (i) Riedl 1983, (j) Willmann 1989, (k) Dollfus \& Cotter 1909, (1) Tebble 1976, (m) Christensen et al. 1978, (n) Poppe \& Goto 1993, (o) Zaccaria 1968, (p) Parenzan 1976, (q) Oschmann 1991, (r) Major 1974, (s) Wagner 1990, (t) Oliverio \& Buzzurro 1994, (u) Nordsieck 1969, (v) Tripodi \& Zanardi 1969, (w) Jensen \& Knudsen 1995, (x) Göthel 1992, (y) Logan 1979, 1983, 1988, (z) Brunton \& Curry 1979; (aa) Zibrowius 1980, 1987, 1988, (bb) H. Zibrowius, pers. comm. 1994. 
1995). The grain-size fractions are equivalent to those of facies D.

The dominance of concave-up shells in facies D indicates that these shells were deposited out of suspension associated with turbulent storm currents (Futterer 1978), or were redeposited on leesides of migrating bedforms (Clifton \& Boggs 1970). The latter is more likely, as they occur in cross-stratified sediment interpreted by Hansen (1999) as having been deposited during storms.

The occurrence of the burrowing echinoderm Echinocyamus pusillus in shelly gravel and sand is well documented from various areas (Airaghi 1930, Mortensen 1948, Nichols 1959, Riedl 1983). Telford et al. (1983) showed that it most commonly occurs in substrates exposed to intensive wave and tidal activity, and exposure to strong currents seems an essential requirement. The common occurrence of E. pusillus in facies D and $\mathrm{E}$ therefore seems to indicate that these sediments were derived from shallow water above the fair-weather base.

The burrowing bivalve Ervilia castanea occupies coarse-grained, well-sorted sediments in the infralittoral zone. This bivalve can be numerically dominant and may rebury itself within 15 seconds. The latter activity is facilitated by the well developed foot (Rooij-Schuiling 1973, Morton 1990). Ervilia castanea, which is particularly abundant in facies E (sample 14/89), occurs with Echinocyamus pusillus. This suggests that the species probably lived in the same type of habitat characterised by current activity and sedimentation.

Autochthonous specimens of Arctica islandica, Glycymeris glycymeris and Echinocardium cordata in facies E evidently show that the sea bottom in the depositional environment could be colonised periodically (Fig. 6). The substrate consistency was comparable to a softground (Table 3). Some of the recorded molluscs, such as chitons and trochid gastropods in facies E (e.g., samples R90/41 and 14/89), are typical of rocky coasts. They indicate that submerged rocky bottoms occurred in close vicinity to the depositional environment. The bottoms were exposed to waves or sea currents, as also indicated by the presence of Ostrea spp. However, as mentioned earlier, these molluscs could have migrated from the rocky bottoms instead of being transported by sea currents. The coralligenous bottoms are likely to have been partly covered by vegetation such as seaweeds. Epibenthos, such as trochid gastropods, might have lived on this vegetation (Pérès 1967, Gamulin-Brida 1967, Fornos \& Ahr 1997). Spinula exisa and Lophelia pertusa are also present in facies E of the Cape Arkhangelos Calcarenite. These species now live in the bathyal zone in the Mediterranean Sea (Table 3). The fossils may have been eroded from older deposits of Lindos Bay Clay and transported seawards. Besides such reworked fossils, the macrofaunal contents of the Cape Arkhangelos Calcarenite are derived from a number of contemporaneous biocoenoses.
The type section for the Cape Arkhangelos Calcarenite is a coastal outcrop at Cape Arkhangelos (southeast of Arkhangelos). This succession of giant foresets also contains coralline red algae in abundance. Invertebrate fossils such as Argyrotheca cordata, Pecten jacobaeus and Echinocyamus pusillus probably came from the infralittoral or the upper part of the circalittoral zone. Seawards, the facies group interfingers with muddy deposits that contain brachiopods from deeper waters, probably more than $100 \mathrm{~m}$ (Hanken et al. 1996). This suggests that the Cape Arkhangelos Calcarenite at Kallithea is likely to have been deposited in the upper part of the circalittoral zone.

Windmill Bay Boulder Bed. - The Windmill Bay Boulder Bed consists mainly of rounded boulders probably eroded from the Cape Arkhangelos Calcarenite, which must have been somewhat cemented before it was abraded. The even distribution of the coralline red algae and bryozoans encrusting the boulders indicates formation above the storm-wave base. The encrustations suggest a marine environment with well-oxygenated water and a low sedimentation rate (see Pérès \& Picard 1964, Pérès 1967, Gamulin-Brida 1967, Bosence 1985, Basso et al. 1998). The encrusters were derived from a coralligenous biocoenosis characterised by a dominance of coralline red algae (e.g., Pérès \& Picard 1964, Pérès 1967).

Kleopolu Calcirudite. - Autochthonous and parautochthonous fossils are absent from the Kleopolu Calcirudite, and the diversity of fossils is therefore very low. Allochthonous coralline red algae were probably derived from coralligenous biocoenoses in a shallow-marine environment (see Pérès \& Picard 1964, Bosence 1985, Basso et al. 1998). Coralline red algae prefer environments in which the sedimentation rate is low (Pérès 1967, Gamulin-Brida 1967). The abrasion and fragmentation of the red algae indicate that deposition took place in a high-energy coastal environment such as a beach. In its type section in the northeastern part of Lindos, the Kleopolu Calcirudite is similarly dominated by coralline red algae, and Hanken et al. (1996) believed it was deposited in a high-energy coastal environment.

Influence of diagenesis on the preservation of the fossil fauna. - Diagenesis may well have had a significant effect on the diversity and density of fossils in the Kallithea succession. In the Lindos Bay Clay, shell material composed of aragonite is common and there are no indications of selective dissolution of aragonite, probably due to the low permeability of the sediment. These well preserved fossils contrast sharply with the situation in the Cape Arkhangelos Calcarenite, where shell material composed of calcite tends to be better preserved than that formed of aragonite. The latter is commonly absent in the samples. The occurrence of 
biomoulds after gastropods in some samples of the Cape Arkhangelos Calcarenite indicates that aragonitic shells originally were present. The Windmill Bay Boulder Bed and Kleopolu Calcirudite show a profound lack of aragonitic shells. We conclude that the macrofaunas of the Cape Arkhangelos Calcarenite, Windmill Bay Boulder Bed and Kleopolu Calcirudite were affected by taphonomical processes before final deposition, but also represent diagenetic relicts of previous biocoenoses.

\section{Conclusions}

By using the invertebrate fossils, we have shown that most of the Kallithea succession can evidently be assigned to the Pleistocene. This is consistent with microfaunal indications of Plio-Pleistocene deposits from neighbouring areas along the east coast of Rhodes. However, the global stratigraphical range of most of the taxa is too long to establish a detailed biozonation. The macrofauna of the Kallithea succession, which confirms warm-temperate conditions in the northern Mediterranean Sea during the Pleistocene, reflects past changes in palaeoenvironmental conditions ranging from deeper water to coastal rocky environments within the circalittoral and infralittoral zones. These changes are recorded by shifts in the occurrences of invertebrate fossils. Since most of the invertebrate fossils have living counterparts, comparisons with recent biocoenoses have enabled us to conclude that the lowermost deposits of the Kallithea succession probably comprise a previously unknown upper part of the Lindos Bay Clay. This comparative approach based on macrofaunal analysis has been successfully applied to the recognition of different types of marine biocoenoses in the entire succession. Remains of these biocoenoses are representative of various habitats, allowing genetic interpretations of each facies group and forming the basis for a better understanding of the depositional system. This includes parameters such as coastal vicinity, depth, salinity and sedimentation:

(1) Lindos Bay Clay was probably formed in the upper circalittoral zone, where sea bottom was characterised by fully marine conditions, well-oxygenated water and generally low sedimentation rate. The presence of plant remains and pteropods indicates that deposition occurred in coastal vicinity under open marine conditions.

(2) The macrofauna of the Cape Arkhangelos Calcarenite indicates a generally higher hydrodynamic energy level over the sea bottom. The mediolittoral, infralittoral, and upper circalittoral zones were potential sediment sources, whereas the final deposition probably occurred in the infralittoral and the upper circalittoral zones. The sedimentation rate varied between moderate and high. In particular, the upper parts of the Cape Arkhangelos Calcarenite show evidence of migrating bedforms deposited during storms. The sea bottom in the depositional environment became colonised periodically by macrofauna. Sediments were derived from areas above the fair-weather base exposed to current activity and active sedimentation. Submerged rocky bottoms exposed to waves or sea currents existed in close vicinity to the depositional environment.

(3) The encrusted boulders of the Windmill Bay Boulder Bed were formed above the storm-wave base within well-oxygenated water and with low sedimentation rate.

(4) The coralline algae of the Kleopolu Calcirudite were formed in a shallow-marine environment with low sedimentation rate. The coralline algae became reworked and deposited in a high-energy coastal environment such as a beach.

\section{Acknowledgements}

The paper benefited greatly from the Master's thesis of the senior author, completed at the Geological Institute (University of Copenhagen) under the supervision of Richard G. Bromley. The study was carried out with support from Kirsten Nielsen, Leif K. Nielsen (Rungsted) and Lotte Q. Nielsen (Copenhagen), and fruitful discussions with the Danish Rhodes Research Group. Jørgen Knudsen (Copenhagen) and Stein-Erik Lauritzen (Bergen) gave valuable comments on bivalves and U/Th dating, and Helmut Zibrowius (Aix Marseille) identified the corals and serpulids. Financial support for fieldwork was kindly provided by the University of Copenhagen and the Danish charter airline Conair. The Carlsberg Foundation enabled the completion of this paper through a postdoctoral scholarship to the senior author (project No. 04-0256/20). The third author acknowledges Statoil ASA for financial support. We thank the Director of the Institute of Geology and Mineral Exploration (Athens, Greece) for permission to conduct fieldwork on Rhodes. Aleksandra Bitner (Warszawa) and Michal Mergl (Plzeň) kindly provided constructive review comments.

\section{References}

Аввотт, R.T. 1991. Seashells of the Northern Hemisphere. 191 pp. Dragon's World Ltd, Limpsfield.

AIRAGHI, C. 1930. Echinidi del Quaternario antico dell'isola di Rodi (Dodecaneso). Atti della Società italiana di Scienze naturali e del Museo civico di Storia naturale di Milano 67, 311-318.

AsgaARD, U. \& BRomley, R.G. 1990. Colonization by micromorphic brachiopods in the shallow subtidal of the eastern Mediterranean Sea, 261-264. In MACKInNON, D.I., LEE, D.E. \& CAMPBELL, J.D. (eds) Brachiopods through Time. Balkema, Rotterdam. 
Asgaard, U. \& Bromley, R.G. 1996. Sømusene og korsridderne. Varv 1996(2), 43-50.

BADEN-Powell, D.F.W. 1955. The correlation of the Pliocene and Pleistocene marine beds of Britain and the Mediterranean. Proceedings of the Geologists' Association 66, 271-292.

BARASH, A. \& DANIN, Z. 1988. Marine Mollusca at Rhodes. Israel Journal of Zoology 35, 1-74.

BARAsh, A. \& DANin, Z. 1992. Fauna Palaestina. Mollusca I. Annotated list of Mediterranean molluscs of Israel and Sinai. 405 pp. The Israel Academy of Sciences and Humanities, Keterpress Enterprises, Jerusalem.

Basso, D., Fravega, P., Piazza, M. \& Vannucci, G. 1998. Biostratigraphic, paleogeographic and paleoecological implications in the taxonomic review of Corallinaceae. Rendiconti Lincei Scienze Fisiche e Naturali series 9, 9, 201-211.

BAtHuRST, R.G.C. 1966. Boring algae, micrite envelopes and lithification of molluscan biosparites. Geological Journal 5, 15-32.

BAthurst, R.G.C. 1975. Carbonate sediments and their diagenesis. 658 pp. Elsevier, Amsterdam.

BÉ, A.W.H. \& GILMER, R.W. 1977. A zoogeographic and taxonomic review of euthecosomatous Pteropoda, vol. 1, 733-808. In Ramsay, A.T.S. (ed.) Oceanic Micropalaeontology. Academic Press, London.

Benda, L. \& MeulenKamp, J.E. 1972. Discussion on biostratigraphic correlations in the Eastern Mediterranean Neogene. Deutsche Geologische Gesellschaft, Zeitschrift 123, 559-564.

BERnASCONI, M.P. \& RoBBA, E. 1993. Molluscan palaeoecology and sedimentological features: an integrated approach from the Miocene Meduna section, northern Italy. Palaeogeography, Palaeoclimatology, Palaeoecology 100, 267-290.

Bevilacqua, A. 1928. Studi sulla fauna fossile marina Pliocenica e Quaternaria dell'isola di Rodi (Egeo). Atti della Società italiana di Scienze naturali e del Museo civico di Storia naturale di Milano 67, 150-178.

BitNer, M.A. 1990. Middle Miocene (Badenian) brachiopods from the Roztocze Hills, south-eastern Poland. Acta Geologica Polonica 40, 129-157.

BLANC, J.J. 1968. Sedimentary geology of the Mediterranean Sea. Oceanography and Marine Biology, An Annual Review 6, 377-454.

BosENCE, D.W.J. 1983. Coralline algal reef frameworks. Journal of Geological Society, London 140, 365-376.

Bosence, D.W.J. 1985. The "Coralligène" of the Mediterranean - a recent analog for Tertiary coralline algal limestones, 216-225. In Toomey, D.F. \& Nitecki, M.H. (eds) Paleoalgology. Springer-Verlag, Berlin.

BRAmbilla, L. \& LuALDI, A. 1988. Il Pliocene della Valle Olona (Varese, Italia NW) nelle Collezioni Sordelli 1874-79, Parona 1883 e Nangeroni 1928. Atti della Società italiana di Scienze naturali e del Museo civico di Storia naturale di Milano 129, $5-32$.

BROEKMAN, J.A. 1973. Sedimentary structures and paleoecology of the Pliocene Kritika Formation in a section near Kalithies (Rhodos, Greece). I. Proceedings of the Koninklijke Nederlandse Akademie van Wetenschappen, Series B, Physical Sciences 76, 423-436.

Bromley, R.G. \& AsGaARD, U. 1975. Sediment structures produced by a spatangoid echinoid: a problem of preserva- tion. Bulletin of the Geological Society of Denmark 24, 261-281.

Bromley, R.G. \& AsgaArd, U. 1993. Two bioerosion ichnofacies produced by early and late burial associated with sea-level change. Geologische Rundschau 82, 276-280.

Brunton, C.H.C. \& CURRY, G.B. 1979. British Brachiopods. Keys and notes for the identification of the species. 64 pp. Academic Press, London.

Cerulli-Irelli, S. 1907. Fauna malacologica mariana. Ostreidae, Anomiidae, Spondilidae, Radulidae, Pectinidae, Mytilidae, Arcidae, Nuculidae, Carditidae, Astartidae. Palaeontographia Italica 13, 65-140.

Cerulli-Irelli, S. 1908. Fauna malacologica mariana. Leptonidae, Galeommidae, Cardiidae, Chamidae, Cyprinidae, Veneridae. Palaeontographia Italica 14, 1-64.

Cerulli-Irelli, S. 1909. Fauna malacologica mariana. Cyrenidae, Donacidae, Psammobiidae, Solenidae, Mesodesmatidae, Mactridae, Cardiliidae, Myidae, Corbulidae, Glycymeridae, Gastrochaenidae, Thyasiridae, Diplodontidae, Lucinidae, Tellinidae, Scrobiculariidae, Cuspidariidae, Pandoridae, Verticordiidae, Lyonsiidae, Anatinidae, Pholadomyidae, Clavagellidae. Palaeontographia Italica 15, 125-214.

Cerulli-Irelli, S. 1910. Fauna malacologica mariana. Parte Querta. - Scaphopoda: Dentaliidae. Gastropoda: Stenogyridae, Gadiniidae, Actaeonidae, Tornatinidae, Scaphandridae, Bullidae, Ringiculidae, Philinidae, Umbrellidae, Conidae, Pleurotomidae. Palaeontographia Italica 16, 23-70.

Cerulli-Irelli, S. 1911. Fauna malacologica mariana. Parte Quinta. - Cancellariidae, Marginellidae, Mitridae, Fusidae, Chrysodomidae, Buccinidae, Nassidae, Columbellidae, Muricidae, Tritonidae, Cassididae, Cypraeidae, Chenopodidae. Palaeontographia Italica 17, 229-276.

Cerulli-Irelli, S. 1912. Fauna malacologica mariana. Parte sesta. - Cerithiidae, Cerithiopsidae, Triforidae, Diastomidae, Vermetidae, Turritellidae, Mathildidae, Caecidae. Palaeontographia Italica 18, 141-170.

ChIRLI, C. 1995. Il genere Caecum Fleming 1817 nel Pliocene Toscano. Bollettino Malacologico 31, 21-27.

Christensen, J.M., LARSEN, S. \& Nyström, B.O. 1978. Havmuslinger. 125 pp. Gyldendals Grønne Håndbøger, Nordiske Forlag, Copenhagen.

Clifton, H.E. \& BogGS, S. JR. 1970. Concave-up pelecypod (Psephidea) shells in shallow marine sand, Elk River Beds, southwestern Oregon. Journal of Sedimentary Petrology 40, 888-897.

Cornée, J.-J., Moissette, P., JoAnnin, S., SuC, J.-P., Quillévéré, F., Krijgsman, W., Hilgen, F., Koskeridou, E., MÜNCH, P., LÉCUYER, C. \& Desvignes, P. In press. Tectonic and climatic controls on coastal sedimentation: The Late Pliocene-Middle Pleistocene of northeastern Rhodes, Greece. Sedimentary Geology.

CURRY, D. 1971. The occurrence of pre-Quaternary pteropods, 595. In FunNell, B.M. \& RIEDEL, W.R. (eds) The Micropalaeontology of Oceans. Cambridge University Press, Cambridge.

Dahlgren, T.G., Weinberg, J.R. \& Halanych, K.M. 2000. Phylogeography of the ocean quahog (Arctica islandica): influences of paleoclimate on genetic diversity and species range. Marine Biology 137, 487-495.

D'Angelo, G. \& Gargiullo, S. 1981. Guida alle Conchiglie 
Mediterranee Conoscerle Cercarle Collezionarle. $2^{\text {nd }}$ edition. 223 pp. Fabbri Editori, Milano.

Dell'ANGelo, B. \& Forli, M. 1995. I poliplacophora del Pleistocene inferiore di Riparbella (Pisa), con elenco dei molluschi rinvenuti. Bollettino Malacologico 30(1994), 221-252.

DeRmitZAKis, M.D. \& GeORGiades-DikeOulia, E. 1979. Macrofauna and planktonic foraminifera of the Armenopetra section in Keratokampos-Viannou area (E. Crete). Annales Géologiques des Pays Helléniques, Tome hors série 1, 309-314.

Dermitzakis, M.D. \& Georgiades-Dikeoulia, E. 1984. Biostratigraphic and chronostratigraphic correlations of the late Cenozoic bivalves of the Hellenic area. Annales Géologiques des Pays Helléniques 32, 197-209.

DermitZAKis, M. \& Georgiades-Dikeoulia, E. 1987. Biozonation of the Neogene invertebrate megafauna of the Hellenic area. Annales Instituti Geologici Publici Hungarici 70, 125-137.

Dollfus, G.F. \& CotTER, J.C.B. 1909. Mollusques tertiaires du Portugal. Le Pliocène au nord du Tage (Plaisancien). I. Pelecypoda. 103 pp. Commission du Service Géologique du Portugal, Imprimerie Nationale, Lisbonne.

DounAS, C.G. \& KoukOuRAS, A.S. 1992. Circalittoral macrobenthic assemblages of Strymonikos Gulf (North Aegean Sea). Marine Ecology 13, 85-99.

FISCHER, M.P. 1877. Paléontologie des terrains Tertiaires de l'Ile de Rhodes. Mémoires de la Société Géologique de France, Series 3(1), 1-74.

FORBES, E. 1844. Report on the Mollusca and Radiata of the Aegean Sea, and on their distribution, considered as bearing on geology. Report British Association for the Advancement of Science 1843, 130-193.

ForNOS, J.J. \& AHR, W.M. 1997. Temperate carbonates on a modern, low-energy, isolated ramp: the Balearic platform, Spain. Journal of Sedimentary Research 67, 364-373.

Froget, C., Thommeret, J. \& Thommeret, Y. 1972. Mollusques septentrionaux en Mediterranée occidentale: datation per le 14C. Palaeogeography, Palaeoclimatology, Palaeoecology 12, 285-293.

FutTERER, E. 1978. Untersuchungen über die Sink- und Transportgeschwindigkeit biogener Hartteile. Neues Jahrbuch für Geologie und Paläontologie, Abhandlungen 155, 318-359.

Gamulin-BRidA, H. 1967. The benthic fauna of the Adriatic Sea. Oceanography and Marine Biology, An Annual Review 5, $535-568$.

Georgiades-Dikeoulia, E. 1979. Paleoenvironmental observations based on a macrofauna of the Pliocene section Prassa, Crete. Annales Géologiques des Pays Helléniques, Tome hors série 1, 439-447.

GHOSH, A.K. 2002. Cenozoic coralline algal assemblage from southwestern Kutch and its importance in palaeoenvironment and palaeobathymetry. Current Science 83, 153-158.

Giannuzzi-Savelli, R., Pusateri, F., Palmeri, A. \& Ebreo, C. 1994. Atlante delle Conchiglie Marine del Mediterraneo. Vol. 1, 125 pp. La Conchiglia, Roma.

GiLAT, E. 1969. Study of an Ecosystem in the Coastal Waters of the Ligurian Sea. III. Macrobenthic Communities. Bulletin de l'Institut Océanographique, Monaco 69(1396), 1-76.

GöTHEL, H. 1992. Farbatlas Mittelmeerfauna. Niedere tier und Fische. 318 pp. Eugen Ulmer Gmbh \& Co., Stuttgart.

HANDFORD, C.R. \& LOUCKS, R.G. 1993. Carbonate depositional sequences and system tracts - responses of carbonate platforms to relative sea-level changes, 3-41. In LOUCKS, R.G. \& SARG, J.F.R. (eds) Carbonate sequence stratigraphy. Recent developments and applications. American Association of Petroleum Geologists Memoir 57.

Hanken, N.-M., Bromley, R.G. \& Miller, J. 1996. Plio-Pleistocene sedimentation in oscillating grabens north-east Rhodes, Greece. Geological Journal 31, 271-296.

HANSEN, K.S. 1999. Development of a prograding carbonate wedge during sea level fall: Lower Pleistocene of Rhodes, Greece. Sedimentology 46, 559-576.

HAYS, J.D. \& BERGGREN, W.A. 1971. Quaternary boundaries and correlations, 669-691. In FunNell, B.M. \& RiedEL, W.R. (eds) The Micropalaeontology of Oceans. Cambridge University Press, Cambridge.

Herman, Y. 1971. Vertical and horizontal distribution of pteropods in Quaternary sequences, 463-486. In FunNELL, B.M. \& RiEDEL, W.R. (eds) The Micropalaeontology of Oceans. Cambridge University Press, Cambridge.

Herman, Y. 1973. Preliminary pteropod results from the Mediterranean Sea. Initial Report of the Deep Sea Drilling Project 13(2), 993-1001.

JENSEN, K.R. \& KNUDSEN, J. 1995. Annotated Checklist of Recent Marine Molluscs of Danish Water. 73 pp. Published by authors, Copenhagen.

KERAUDREN, B. 1970. Les formations quarternaires marines de la Grèce. Bulletin du Musée d'Anthropologie Préhistorique de Monaco 16, 5-148.

Kontogianni, V.A., Tsoulos, N. \& Stiros, S.C. 2002. Coastal uplift, earthquakes and active faulting of Rhodes Island (Aegean Arc): modeling based on geodetic inversion. Marine Geology 186, 299-317.

Kovacs, E. \& SPJELDNAES, N. 1999. Pliocene-Pleistocene stratigraphy of Rhodes, Greece. Newsletters on Stratigraphy 37, 191-208.

LELLÁK, J. 1978. Snegle og Muslinger fra Havet. 184 pp. Fremad, Copenhagen.

LoGAN, A. 1979. The recent Brachiopoda of the Mediterranean Sea. Bulletin de l'Institut Océanographique, Monaco 72(1434), 1-112.

LoGAN, A. 1983. Brachiopoda collected by CANCAP I-III expeditions to the south-east North Atlantic. 1976-1978. Zoologische Mededelingen 57(18), 165-189.

LOGAN, A. 1988. Brachiopoda collected by CANCAP IV and VI expeditions to the south-east North Atlantic. 1980-1982. Zoologische Mededelingen 62(5), 59-74.

LUTHER, W. \& FiEDLER, K. 1976. A Field Guide to the Mediterranean Sea Shore. 272 pp. Collins, London.

Lønøy, A. \& Hanken, N.-M. 1989. Clastic Carbonate Deposition in Response to Faulting: An Example from the Isle of Rhodes, Greece. 23 pp. Project No. RA 423A. Preliminary study. Unpublished Norsk Hydro report, Bergen.

Løvlie, R., Støle, G. \& SpJELDnÆS, N. 1989. Magnetic polarity stratigraphy of Pliocene-Pleistocene marine sediments from Rhodes, eastern Mediterranean. Physics of the Earth and Planetary Interiors 54, 340-352.

MARI, A. \& ZANARDI, G. 1971. Guide to Mediterranean conchology. La Conchiglia, year 3(28), pp. 6, 8.

MaJor, A. 1974. Collecting World Sea Shells. 187 pp. John Bartholomew \& Son, Edinburgh. 
MeulenKamP, J.E. 1985. Aspects of the Late Cenozoic evolution of the Aegean region, 307-321. In STANLEY, D.J. \& WeZEL, F.-C. (eds) Geological Evolution of the Mediterranean Basin. Springer-Verlag, New York.

MeulenKamp, J.E., Mulder, E.F.J. De \& Weerd, A. van DE 1972. Sedimentary history and paleogeography of the Late Cenozoic of the Island of Rhodos. Zeitschrift Deutsche Geologische Gesellschaft 123, 541-553.

MigliorinI, C. 1925. Notizie sulla morfologia di Rodi. L'Universo 6, 81-95. (Geological map 1 : 100,000.)

Migliorini, C.I. 1934a. Cenni sull'isola di Rodi. Bollettino della Società Geologica Italiana 52(2), XL-LXI.

MigLiorini, C.I. 1934b. Guida alle escursioni nell'isola di Rodi. Bollettino della Società Geologica Italiana 52(2), LXXIV-CIII.

Moissette, P. \& Spjeldnaes, N. 1995. Plio-Pleistocene deepwater bryozoans from Rhodes, Greece. Palaeontology 38, 771-799.

Mortensen, T. 1948. A Monograph of the Echinoidea. IV (2). Clypeastroida. Clypeastridae, Arachnoididae, Fibulariidae, Laganidae and Scutellidae. 471 pp. C.A. Reitzel, Copenhagen.

MorTON, B. 1990. The biology and functional morphology of Ervilia castanea (Bivalvia: Tellinacea) from the Azores. Acoreana 1990, Supplement, 75-96.

Mutti, E., Orombelli, G. \& PozZI, R. 1970. Geological studies on the Dodecanes Islands (Aegean Sea). IX. Geological map of the island of Rhodes (Greece). Explanatory notes. Annales Géologiques des Pays Helléniques 22, 74-226.

NichOLS, D. 1959. Changes in the Chalk heart-urchin Micraster interpreted in relation to living forms. Royal Society of London, Philosophical Transactions B242, 347-437.

NIELSEN, J.K. 1997. Spor- og Kropsfossiler i Kvartcere Marine Sedimenter ved Kallithea, Rhodos, Grcekenland. (Trace Fossils and Body Fossils in Quaternary Marine Sediments at Kallithea, Rhodes, Greece), 655 pp. Master thesis, University of Copenhagen, Denmark.

NiELSEN, J.K. 1999. Commensal association of Corbula gibba (Bivalvia) and a sub-conical boring. Bulletin of the Geological Society of Denmark 45, 135-138.

Nikiforova, K.V. \& AleKseEv, M.N. 1997. International geological correlation program, Project 41: Neogene/Quaternary boundary, 3-12. In Couvering, J.A. van (ed.) The Pleistocene boundary and the beginning of the Quaternary. Cambridge University Press, Cambridge.

NORDSIECK, F. 1968. Die europäischen Meeres-Gehäuseschnecken (Prosobranchia). Vom Eismeer bis Kapverden und Mittelmeer. 273 pp. Gustav Fischer Verlag, Stuttgart.

NORDSIECK, F. 1969. Die europäischen Meeresmuscheln (Bivalvia). Vom Eismeer bis Kapverden, Mittelmeer und Schwarzes Meer. 256 pp. Gustav Fischer Verlag, Stuttgart.

Oliverio, M. \& BuZzUrRo, G. 1994. A new mediterranean species of the genus Homalopoma, with notes on the genus-group (Trochoidea, Turbinidae, Colloniinae). Bollettino Malacologico 30, 182-188.

Orombelli, G. \& Montanari, C. 1967. Geological studies on the Dodecanese Islands (Aegean Sea). VI. The Calabrian of the Island of Rhodes (Greece). Bollettino della Società Geologica Italiana 86, 103-113.

OSCHMANN, W. 1991. Ecology and bathymetry of the late Quater- nary shelly macrobenthos from bathyal and abyssal areas of the Norwegian Sea. Senckenbergiana Maritima 21, 155-189.

Parenzan, P. 1976. Carta d'identità delle conchiglie del Mediterraneo. Vol. II Bivalvi. Sec. parte. 546 pp. Bios Taras Editrice, Taranto.

Pasini, G. \& Colalongo, M.L. 1997. The Pliocene-Pleistocene boundary-stratotype at Vrica, Italy, 15-45. In COUVERING, J.A. vAn (ed.) The Pleistocene Boundary and the Beginning of the Quaternary. Cambridge University Press, Cambridge.

PEACOCK, J.D. 1993. Late Quaternary marine mollusca as palaeoenvironmental proxies: a compilation and assessment of basic numerical data for NE Atlantic species found in shallow water. Quaternary Science Reviews 12, 263-275.

PÉRÈS, J.-M. 1967. The Mediterranean benthos. Oceanography and Marine Biology, An Annual Review 5, 449-533.

PÉrès, J.-M. \& Molinier, R. 1957. Compte/rendu du colloque tenue à Gênes par la comité du benthos de la Commission Internationale pour l'Exploration Scientifique de la Mer Mediterranée. Recueil des travaux de la Station marine d'Endoume, Marseille 22(13), 5-15.

PÉRÈs, J.-M. \& PICARD, J. 1964. Nouveau manuel de bionomie benthique de la mer Méditerranée. Recueil des travaux de la Station marine d'Endoume, Marseille 47(31), 3-137.

PICARD, J. 1965. Recherches qualitatives sur les biocoenoses marines des substrats meubles dragables de la région Marseillaise. Recueil des travaux de la Station marine d'Endoume, Marseille 52(36), 1-160.

Pirazzoli, P.A., Montaggioni, L.F., Saliège, J.F., Segonzac, G., Thommeret, Y. \& VergnAud-GrazZINI, C. 1989. Crustal block movements from Holocene shorelines: Rhodes Island (Greece). Tectonophysics 170, 89-114.

Pirazzoli, P.A., Montaggioni, L.F., Thommeret, J., ThomMERET, Y. \& LABOREL, J. 1982. Sur les lignes de rivage et la néotectonique a Rhodes (Grèce). Annales de l'Institut Océanographique 58, 89-102.

Poppe, G.T. \& Goto, Y. 1991. European Seashells. Volume I. (Polyplacophora, Caudofoveata, Solenogastra, Gastropoda). 352 pp. Verlag Christa Hemmen, Wiesbaden.

PopPe, G.T. \& Goto, Y. 1993. European Seashells. Volume II. Scaphopoda, Bivalvia, Cephalopoda. 221 pp. Verlag Christa Hemmen, Wiesbaden.

RAFFI, S. 1986. The significance of marine boreal molluscs in the Early Pleistocene faunas of the Mediterranean area. Palaeogeography, Palaeoclimatology, Palaeoecology 52, 267-289.

Rasmussen, T.L., Hastrup, A. \& Thomsen, E. 2005. Lagoon to deep-water foraminifera and ostracods from the Plio-Pleistocene Kallithea Bay section, Rhodes, Greece. Cushman Foundation for Foraminiferal Research, Special Publication 39, 1-290.

RIEDL, R. (ed.) 1983. Fauna und Flora des Mittelmeeres. Ein systematischer Meeresführer für Biologen und Naturfreunde. $3^{\text {rd }}$ edition, 836 pp. Verlag Paul Parey, Hamburg.

Rio, D., RAFFI, I. \& BACKMAN, J. 1997. Calcareous nannofossil biochronology and the Pliocene-Pleistocene boundary, 63-78. In COUVERING, J.A. VAN (ed.) The Pleistocene boundary and the beginning of the Quaternary. Cambridge University Press, Cambridge.

RoOIJ-SCHUILING, L.A. DE 1973. A preliminary report on systematics and distribution of the genus Ervilia Turton, 1822 (Mesodesmatidae, Bivalvia). Malacologia 14, 236-241. 
Sabelli, B., GiannuZZi-Savelli, R. \& Bedulli, D. 1990-1992. Annotated check-list of Mediterranean marine Mollusks, 3 vols. 781 pp. Libreria Naturalistica Bolognese, Bologna.

SCHLAGER, W. 1981. The paradox of drowned reefs and carbonate platforms. Geological Society of America Bulletin 92, 197-211.

SNeli, J.-A. 1975. Mollusca, Prosobranchia, Forgjellesnegler. $55 \mathrm{pp}$. Universitetsforlaget, Trondheim.

SPOEL, S. VAN DER 1967. Euthecosomata. A group with remarkable developmental stages (Gastropoda, Pteropoda). 375 pp. J. Noorduyn en Zoon, N.V., Gorinchem.

Stolfa ZuCChi, M.L. 1977. Gasteropodi recenti delle lagune di Grado e Marano. Atti della Società italiana di Scienze naturali e del Museo civico di Storia naturale di Milano 118, 144-164.

SøRENSEN, M. 1984. Growth and mortality in two Pleistocene bathyal micromorphic bivalves. Lethaia 17, 197-210.

TebBle, N. 1976. British Bivalve Seashells. A Handbook for Identification. $2^{\text {nd }}$ edition, 212 pp. Her Majesty's Stationary Office, Edinburgh.

TElford, M., HAROLD, A.S. \& MoOI, R. 1983. Feeding structures, behavior, and microhabitat of Echinocyamus pusillus (Echinoidea, Clypeasteroida). Biological Bulletin 165, 745-757.

TERqueM, M.O. 1878. Les foraminifères et les entomostracésostracodes du Pliocène supérieur de l'ile de Rhodes. Mémoires de la Société Géologique de France, Série 3, 1(3), 1-135.

TRIPODI, C. \& ZANARDI, G. 1969. La ricerca delle conchiglie. $L a$ Conchiglia, year 1(9-10), pp. 7, 10, 12-14.

VERDUIN, A. 1976. On characters, variability, and distribution of the European marine gastropods Bittium latreillii (Payraudeau) and Bittium lacteum (Philippi). Basteria 40, 133-142.

VERDUIN, A. 1982. On taxonomy and variability of Recent European species of the genus Bittium Leach (Mollusca, Gastropoda, Prosobranchia). Basteria 46, 93-120.

WAGNER, H.P. 1991. Review of the European Pectinidae. Vita marina 41(1), 1-48.

Willmann, R. 1989. Muscheln und Schnecken der Nord- und Ostsee. 310 pp. Verlag J. Neumann-Neudamm, Melsungen.

WiLson, J.L. 1975. Carbonate Facies in Geologic History. 471 pp. Springer-Verlag, Berlin.

ZACCARIA, M. 1968. Studi geologici sulle isole del Dodecaneso (Mare Egeo). VIII. Fauna calabriana dell'isola di Rhodi. Rivista Italiana di Paleontologia 74, 275-306.

Zenetos, A., Vardala-Theodorou, E. \& Alexandrakis, C. 2005. Update of the marine Bivalvia Mollusca checklist in Greek waters. Journal of Marine Biological Association U.K. 85, 993-998.

ZiBrowius, H. 1980. Les Scléractiniaires de la Méditerranée et de l'Atlantique nord-oriental. Mémoire de l'Institut Océanographique, Monaco 11, 1-284.

ZiBrowius, H. 1987. Scléractiniaires et Polychètes Serpulidae des faunes bathyales actuelle et plio-pléistocène de Méditerranée. Documents et Travaux de l'Institut Geologique Albert de Lapparent 11, 255-257.

Zibrowius, H. 1988. Mise au point sur les Scléractiniaires comme indicateurs de profondeur (Cnidaria: Anthozoa). Géologie Méditerranéenne 15, 27-47. 